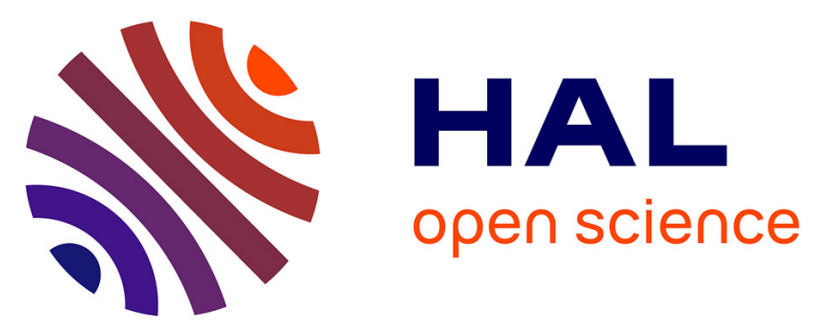

\title{
Characterization of recombinant human growth differentiation factor-9 signaling in ovarian granulosa cells
}

David G. Mottershead, Minna M. Pulkki, Pranuthi Muggalla, Arja

Pasternack, Minna Tolonen, Samu Myllymaa, Olexandr Korchynskyi, Yoshihiro Nishi, Toshihiko Yanase, Stan Lun, et al.

\section{To cite this version:}

David G. Mottershead, Minna M. Pulkki, Pranuthi Muggalla, Arja Pasternack, Minna Tolonen, et al.. Characterization of recombinant human growth differentiation factor-9 signaling in ovarian granulosa cells. Molecular and Cellular Endocrinology, 2008, 283 (1-2), pp.58. 10.1016/j.mce.2007.11.007 . hal-00531962

\section{HAL Id: hal-00531962 https://hal.science/hal-00531962}

Submitted on 4 Nov 2010

HAL is a multi-disciplinary open access archive for the deposit and dissemination of scientific research documents, whether they are published or not. The documents may come from teaching and research institutions in France or abroad, or from public or private research centers.
L'archive ouverte pluridisciplinaire HAL, est destinée au dépôt et à la diffusion de documents scientifiques de niveau recherche, publiés ou non, émanant des établissements d'enseignement et de recherche français ou étrangers, des laboratoires publics ou privés. 


\section{Accepted Manuscript}

Title: Characterization of recombinant human growth differentiation factor-9 signaling in ovarian granulosa cells

Authors: David G. Mottershead, Minna M. Pulkki, Pranuthi Muggalla, Arja Pasternack, Minna Tolonen, Samu Myllymaa, Olexandr Korchynskyi, Yoshihiro Nishi, Toshihiko Yanase,

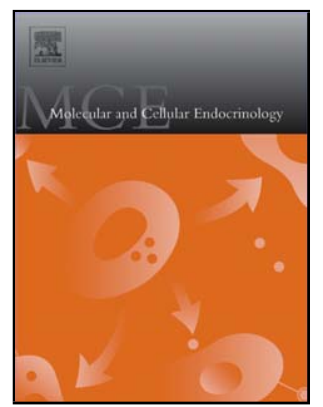
Stan Lun, Jennifer L. Juengel, Mika Laitinen, Olli Ritvos

PII: S0303-7207(07)00427-3

DOI: doi:10.1016/j.mce.2007.11.007

Reference: $\quad$ MCE 6754

To appear in: $\quad$ Molecular and Cellular Endocrinology

Received date: $\quad 22-8-2007$

Revised date: $\quad 12-11-2007$

Accepted date: $\quad$ 13-11-2007

Please cite this article as: Mottershead, D.G., Pulkki, M.M., Muggalla, P., Pasternack, A., Tolonen, M., Myllymaa, S., Korchynskyi, O., Nishi, Y., Yanase, T., Lun, S., Juengel, J.L., Laitinen, M., Ritvos, O., Characterization of recombinant human growth differentiation factor-9 signaling in ovarian granulosa cells, Molecular and Cellular Endocrinology (2007), doi:10.1016/j.mce.2007.11.007

This is a PDF file of an unedited manuscript that has been accepted for publication. As a service to our customers we are providing this early version of the manuscript. The manuscript will undergo copyediting, typesetting, and review of the resulting proof before it is published in its final form. Please note that during the production process errors may be discovered which could affect the content, and all legal disclaimers that apply to the journal pertain. 


\section{Characterization of recombinant human growth differentiation factor-9 signaling in ovarian granulosa cells}

Authors: David G. Mottershead ${ }^{1}$, Minna M. Pulkki ${ }^{1}$, Pranuthi Muggalla ${ }^{1}$, Arja Pasternack ${ }^{1}$, Minna Tolonen ${ }^{1}$, Samu Myllymaa ${ }^{1}$, Olexandr Korchynskyi ${ }^{2}$, Yoshihiro Nishi ${ }^{3}$, Toshihiko Yanase ${ }^{3}$, Stan Lun ${ }^{4}$, Jennifer L. Juengel ${ }^{4}$, Mika Laitinen ${ }^{5}$ and Olli Ritvos ${ }^{1}$.

${ }^{1}$ Department of Bacteriology and Immunology, Haartman Institute, 00014 University of Helsinki, Helsinki, Finland

${ }^{2}$ Thurston Arthritis Research Center, University of North Carolina at Chapel Hill, Chapel Hill NC 27599, U.S.A.

${ }^{2}$ Department of Orthopedic Surgery, School of Medicine, Virginia Commonwealth University, Richmond VA 23298 U.S.A. (Present address)

${ }^{3}$ Department of Medicine and Bioregulatory Science (Third Department of Internal Medicine), Graduate School of Medical Sciences, Kyushu University

${ }^{4}$ AgResearch, Wallaceville Animal Research Centre, P.O.Box 40063, Ward Street, Upper Hutt 5140, New Zealand

${ }^{5}$ Biotechvisions Ltd., Tukholmankatu 8B, 00290 Helsinki

*Contributed equally to this study

Corresponding author: David G. Mottershead, Ph.D.

Haartman Institute, Dept of Bacteriology and Immunology;

PO Box 21 (Haartmaninkatu 3)

FIN-00014 University of Helsinki

Helsinki, Finland

Telephone: +358-9-19126847

Telefax: $+358-9-19126675$

Email: David.Mottershead@,helsinki.fi

Key words: Growth differentiation factor-9 (GDF9), granulosa cells, signaling pathway, human Word count: Text: 4388 Abstract: 240 Figures: 5

Disclosure summary: The authors have nothing to declare. 


\begin{abstract}
Growth differentiation factor-9 (GDF9) is an oocyte secreted paracrine factor essential for mammalian ovarian folliculogenesis. Like other members of the transforming growth factor- $\beta$ (TGFß) superfamily, GDF9 is synthesized as a prepropeptide which needs processing by furin-like proteases to result in an active mature protein. We have previously characterized a preparation of unpurified recombinant mouse GDF9 which is bioactive as produced by human embryonic kidney 293T (HEK-293T) cells. However, we find that unpurified recombinant human GDF9 (hGDF9) produced by HEK-293T cells is not bioactive. Purified recombinant hGDF9 is bioactive and here we report the characterization of this protein. We find that the purified untagged mature region of hGDF9 is active in transcriptional reporter assays specific for Smad3/4 in human granulosa-luteal (hGL) cells. We also demonstrate the use of a BMP (Smad1/5) responsive (BREluciferase) adenovirus in primary cultures of hGL cells to detect BMP responses. Using this adenovirus we find that purified human GDF9 does not activate the Smad1/5 pathway. Purified hGDF9 mature region activated the Smad3 pathway also in the FSH responsive human granulosa tumor cell line KGN. Primary cultures of rat granulosa cells responded to purified hGDF9 with an increase in DNA synthesis as measured by $\left[{ }^{3} \mathrm{H}\right]$-thymidine uptake. Here we also report that the inclusion of a C-terminal affinity purification tag destroys GDF9 bioactivity. This study is the first characterization of purified biologically active human GDF9 and as such is of importance for studies on human fertility, and efforts aimed at treating infertility conditions.
\end{abstract}




\section{Introduction}

Growth differentiation factor-9 (GDF9), identified in the early 1990s (McPherron and Lee 1993) as a member of the transforming growth factor- $\beta$ (TGF $\beta$ ) superfamily, is an oocyte derived factor expressed throughout the development of the maturing follicle (McGrath et al. 1995; Laitinen et al. 1998). The protein functions as a paracrine factor in the regulation of granulosa cell proliferation and differentiation (Elvin et al. 1999; Eppig 2001; Gilchrist et al. 2006), and is essential for fertility, knockout mice displaying arrested follicular development at the primary follicle stage (Dong et al. 1996). In our previous studies we have studied the signaling of recombinant mouse GDF9 (mGDF9) produced by human embryonic kidney 293T (HEK-293T) cells. We have shown that mGDF9 induces Smad2 phosphorylation and inhibin production in rat diethylstilbestrol-treated granulosa cells (Roh et al. 2003) and in human granulosa-luteal (hGL) cells (Kaivo-Oja et al. 2003), not requiring any purification steps to reveal these activities. Further, we have shown that the downstream signaling actions of mGDF9 are mediated by the type I receptor, ALK5, initiating the subsequent activation of Smad2 and Smad3, both in cultured rat granulosa cells (Mazerbourg et al. 2004) and in hGL cells (Kaivo-Oja et al. 2003; Kaivo-Oja et al. 2005). It has also been shown that mGDF9 uses the BMP type II receptor (BMPRII) as its other signaling receptor in rat granulosa cells (Vitt et al. 2002).

To date in vitro analyses of human GDF9 (hGDF9) have been restricted by the lack of a biologically active protein. However, the significance of GDF9 as a regulator of human fertility has been shown with mutation analyses. Mutations in the hGDF9 gene are associated with various reproductive abnormalities. It has been shown that aberrant expression of GDF9 is associated with polycystic ovary syndrome (PCOS) (Teixeira Filho et al. 2002) and screening of women with premature ovarian failure (POF) has revealed mutations in the GDF9 gene (Dixit et al. 2005; Laissue et al. 2006). In 2004 a rare deletion mutation in the hGDF9 gene was described in heterozygous sisters with spontaneous dizygotic twins (Montgomery et al. 2004) and more recently new variants in the hGDF9 gene that are significantly more common in mothers of dizygotic (DZ) twins than controls were described, suggesting that rare GDF9 variants contribute to the likelihood of DZ twinning (Palmer et al. 2006). Although these studies reveal that abnormal expression of GDF9 can lead to adverse effects in fertility, the physiological role of GDF9 in humans is still not totally clear.

For in vitro analyses of human GDF9 function, both purified recombinant protein and functional bioassays to test the signaling pathways utilized are needed. Here we report that, in contrast to mGDF9, hGDF9 is produced in a latent form by HEK-293T cells, and that the position of an affinity purification tag crucially effects GDF9 bioactivity. In this study we have produced various epitope tagged forms of mouse and human GDF9 and purified the respective mature forms. We find that a C-terminal $\mathrm{His}_{6}$ tag destroys GDF9 bioactivity. Most importantly, the purified untagged mature region of hGDF9 was biologically active exhibiting the ability to activate a Smad3/4 specific transcriptional reporter in human granulosa-luteal cells, whereas no activation of the BMP pathway in these cells was observed. Purified hGDF9 mature region activated the Smad3 pathway also in the FSH responsive human granulosa tumor cell line KGN. Finally, in these studies which are the first to characterize a purified biologically active human GDF9, we demonstrate that hGDF9 stimulates DNA synthesis in primary cultures of rat granulosa cells. We believe these results are of particular importance for studies on human fertility, and efforts aimed at treating infertility conditions.

\section{Materials and Methods}

\section{Expression vector construction}

Construction of the mGDF9wt vector has been previously described (Laitinen et al. 1998), in short the mouse GDF9 full-length cDNA was subcloned into the pEFIRES-P expression vector (Hobbs et al. 1998). His 6 tagged vectors were constructed by introducing the affinity tag into the mature region by PCR and by subcloning the proand the mature regions into the pEFIRES-P expression vector. $\mathrm{C} 6 \mathrm{H}$ mGDF9 mature region was amplified with PCR with following primers: (5' primer) 5'-agatctccceggcgecgtcgagggcag-3' and (3' primer) 5'tctagattattagtgatggtgatggtgatgacgacaggtgcacct-3'. N6H mGDF9 mature region was amplified with PCR with following primers: (5' primer) 5'- 
cggcgccgtcgagggcagaaagcccaccatcaccatcaccatatcc gctccgaagcg-3' and (3' primer) 5'tctagattattaacgacaggtgcacct- 3 '. The mouse proregion was digested out of the wild type construct and the pro- along with the tagged mature regions were subcloned into the pEFIRES-P expression vector. Human GDF9 DNA fragments were amplified from human genomic DNA with following primers: (5, primer) 5'tagtccacccacacacctga-3' and (3' primer) 5'tactttgccaaataggctcaag- 3 ' and subcloned into the pEFIRES-P expression vector. $6 \mathrm{H}$-tagged vectors were constructed by introducing the tag into the mature region by PCR and by subcloning the proand the mature regions into the pEFIRES-P expression vector. C6H hGDF9 mature region was amplified with PCR with following primers: (5' primer) 5 '-ggcgccgcagaggtcaggaaactg-3' and (3' primer) 5'-tctagactattagtgatggtgatggtgatgac gacaggtgcactttgt-3'. The human pro-region was digested out of the wild type construct and the pro- along with the tagged mature regions were subcloned into pEFIRES-P expression vector.

\section{Protein expression, purification and analysis}

Development of a HEK-293T cell line expressing mGDF9wt protein has been previously described (Kaivo-Oja et al. 2003). Cell lines expressing epitope tagged processed mouse and human GDF9 were developed by a similar protocol and were used as sources of recombinant GDF9 proteins. Levels of recombinant proteins in 293T cell growth media were compared in immunoblots using the known concentration of mGDF9 conditioned media (1 ng/ul) (Kaivo-Oja et al. 2003) as a standard. 6H-tagged recombinant proteins were purified with affinity chromatography. Briefly, 293T cell growth media containing the protein of interest was centrifuged and filtered through $0.22-0.45 \mu \mathrm{m}$ filter. The cleared media was loaded on a HiTrap Chelating column (GE Healthcare) charged with $\mathrm{Ni}^{2+}$-ions. First, the pro-region of mouse or human GDF9 was washed out of the column under denaturing conditions with urea and the respective mature region was eluted out of the column by increasing imidazole concentration. Finally, human $\mathrm{C} 6 \mathrm{H}$ GDF9 and mouse N6H GDF9 were purified by high performance liquid chromatography (HPLC), a commercial service contracted from the Peptide and Protein Core Facility Laboratory, Haartman Institute, University of Helsinki. Purified fractions were analysed on silver gels and Western blots. Reduced protein fractions (with $10 \mathrm{mM}$ DTT) were run in $15 \%$ SDS-PAGE gels, and stained with silver nitrate and blotted onto a Hybond $\mathrm{C}$ nitrocellulose membrane as described previously (Kaivo-Oja et al. 2003). Blotted membranes were treated with GDF9 specific mAb-53 $(1: 10,000)$ (Gilchrist et al. 2004b) or anti-His primary antibody $(1: 10,000)$ (Amersham) and a secondary antibody, peroxidase-conjugated anti-IgG (Jackson ImmunoResearch Laboratories, Inc.; 1:20,000). Immunoreactive proteins were detected using enhanced chemiluminescence reagents (Amersham Pharmacia Biotech) or alkaline phosphatase based detection (Bio-Rad).

\section{Reagents and growth factors}

TGF- $\beta 1$ was purchased from $R \& D$ Systems (Minneapolis, MN). E. coli produced BMP2 was a kind gift from Dr. Peter Mace (University of Otago, NZ). Fetal calf serum (FCS) was purchased from Euroclone Ltd. (Devon, UK). DMEM and Ham's F-12 were purchased from Invitrogen Life Technologies, Inc. (Gaithersburg, MD). Heparin (Fragmin) was purchased from Pharmacia \& Upjohn (Stockholm, Sweden). BSA was purchased from Roche (Mannheim, Germany). Peroxidase-conjugated rabbit antimouse IgG was purchased from Jackson ImmunoResearch Laboratories, Inc. (West Grove, PA).

\section{Reporter gene constructs}

The pGL3CAGA $_{12}$-luciferase reporter plasmid was provided by Dr. C. H. Heldin (Ludwig Institute for Cancer Research, Uppsala, Sweden) (Dennler et al. 1998). The pGL3BRE-luciferase reporter plasmid (Korchynskyi and ten Dijke 2002) was provided by Dr. P. ten Dijke (The Netherlands Cancer Institute).

\section{hGL cell cultures}

hGL cells were obtained with informed consent from women undergoing in vitro fertilization (IVF) treatments. For each experiment, cells from one to six patients were pooled, enzymatically dispersed, and separated from red blood cells by centrifugation through Ficoll-Paque as previously described (Eramaa et al. 1993). Thereafter, hGL cells were counted and plated at a density of 3$4 \times 10^{4}$ cells/well on 24-well plates (Cellstar, Greiner Bio-one, Frickenhausen, Germany; final concentration, $3-4 \times 10^{4}$ cells $/ \mathrm{ml}$ ). hGL cells were cultured in DMEM supplemented with $10 \%$ FCS, 
$2 \mathrm{mM}$ l-glutamine, and antibiotics $(100 \mathrm{IU} / \mathrm{ml}$ penicillin, $100 \mu \mathrm{g} / \mathrm{ml}$ streptomycin and $0.25 \mu \mathrm{g} / \mathrm{ml}$ amphotericin-B; GIBCO). Cells were cultured 1-2 $\mathrm{d}$ before adenovirus infections and 2-3 d before ligand stimulation experiments.

\section{Adenovirus infections}

The recombinant adenovirus Ad-CAGA9luciferase (Dooley et al. 2003) was provided by Dr. P. ten Dijke (The Netherlands Cancer Institute). Reporter BRE-Luc adenovirus was generated using AdEasy system accordingly to provided protocol (He et al. 1998). Briefly, the cassette that contains the BRE enhancer, minimal MLP promoter, luciferase CDS and polyA signal (Korchynskyi and ten Dijke 2002) was recloned from pGL3 plasmid (Promega) into the pShuttle vector and the construct obtained was recombined with the Easy-1 adenoviral backbone in BJ1583 cells. The linearized cosmid was transfected into 293 cells and amplified as an adenovirus. Viruses were amplified and titrated in transcomplemental 293A cells and purified with cesium chloride gradient ultracentrifugation as described previously (He et al. 1998). The use of recombinant adenoviruses in hGL cultures has been previously optimized (Bondestam et al. 2002). The hGL cells were infected by incubating the cells with viruses at $37^{\circ} \mathrm{C}$ in serum-free DMEM supplemented with l-glutamine and antibiotics for $45 \mathrm{~min}$, and DMEM containing 2\% FCS was added on top to stop the infection. The cells were then incubated for $24 \mathrm{~h}$ before continuing the luciferase-assay experiments.

\section{Transient transfections and luciferase assays}

KGN cells were cultured in DMEM/F12 1:1 supplemented with $10 \%$ FCS, $2 \mathrm{mM}$ l-glutamine, $100 \mathrm{IU} / \mathrm{ml}$ penicillin, and $100 \mu \mathrm{g} / \mathrm{ml}$ streptomycin at $37 \mathrm{C}$ in $5 \% \mathrm{CO}_{2}$. The $\mathrm{KGN}$ cells were plated at low confluency on 24-well plates and grown overnight before transfections. Transfections were performed in $0.5 \mathrm{ml}$ medium with $100 \mathrm{ng} /$ well $\mathrm{CAGA}_{12}$-luciferase reporter construct (Dennler et al. 1998) or the BMP response element (BRE)luciferase reporter construct (Korchynskyi and ten Dijke 2002), and $10 \mathrm{ng} /$ well $\beta$-galactosidase reporter plasmid using the PEI transfection reagent (Polysciences Inc.). Twenty-four hours later KGN cells were starved $4-8 \mathrm{~h}$ in $0.2 \% \mathrm{FCS}$ DMEM and treated with TGF- $\beta$, BMP2, or GDF9 in $0.2 \% \mathrm{FCS} / \mathrm{DMEM}$ for $24 \mathrm{~h}$. Ad-CAGA ${ }_{9}$-luc or Ad-BRE-luc infected hGL cells were treated with
TGF $\beta$, BMP 2 or GDF9 in $2 \%$ FCS/DMEM for 24 $\mathrm{h}$. The cells were then lysed into 1x passive lysis buffer, and luciferase activity was measured with luciferase assay reagent (Promega Corp., Madison, WI) and normalized to $\beta$-galactosidase activity. Data are the mean \pm sem of triplicate determinations from representative experiments, relative to an adjusted value of 1.0 for the mean of the control wells.

\section{Measurement of DNA synthesis}

Determination of the effects of GDF9 on $\left[{ }^{3} \mathrm{H}\right]-$ thymidine incorporation of rat granulosa cells was performed as described (McNatty et al. 2005). All experiments involving rats were approved by the Wallaceville Animal Ethics committee. Briefly, granulosa cells were collected from all surfacevisible follicles approximately $46 \mathrm{~h}$ after i.p. administration of 20 IU eCG (Intervet Ltd, Auckland NZ) to 23-26 day old Sprague-Dawley rats. Isolated cells $(20,000$ cells per well) were incubated in M199 (Earle's salts; Sigma) with 100 $\mathrm{U} / \mathrm{ml}$ penicillin (Invitrogen), $100 \mu \mathrm{g} / \mathrm{ml}$ streptomycin (Invitrogen), 2mM GlutaMax-1 (Invitrogen), $0.23 \mathrm{mM}$ sodium pyruvate (Sigma) $0.3 \mathrm{mg} / \mathrm{ml}$ polyvinyl alcohol (Sigma) with $293 \mathrm{H}$ conditioned media containing untagged mGDF9 (total volume of conditioned media was $40 \%$ in all comparison wells) or purified untagged hGDF9 or C6H tagged hGDF9 at varying concentrations $(0-1000 \mathrm{ng} / \mathrm{nl})$. After $18 \mathrm{~h}$ of culture, methyl- $\left[{ }^{3} \mathrm{H}\right]$-thymidine (Perkin Elmer) was added to each well and cells were harvested for determination of $\left[{ }^{3} \mathrm{H}\right]$-thymidine incorporation 6 hours later. In each assay, each treatment was applied to 4 replicate wells. The bioassay was repeated with 3 separate pools of granulosa cells. The average $\mathrm{cpm}$ for each treatment was calculated as described for each pool of granulosa cells (McNatty et al. 2005) Differences between controls and treatments or between treatments were analyzed using the paired t-test function of Microsoft Excel 2003. Data were transformed (natural $\log$ ) prior to analyses. 


\section{Results}

Mouse GDF9 is produced by HEK-293T cells in a biologically active form whereas human GDF9 is produced in a latent form.

In contrast to mouse GDF9 (mGDF9), human GDF9 (hGDF9) is not produced by HEK-293T cells in an active form (Fig 1A). In these initial studies, Smad3 activation was monitored by transducing human granulosa-luteal (hGL) cells with an adenovirus encoding the CAGAluciferase reporter (Kaivo-Oja et al. 2005), which contains repeats of the Smad3/4 response element (GTCT/AGAC) in front of the luciferase cDNA (Dennler et al. 1998). This lack of bioactivity in the case of hGDF9 was not due to a problem in the production of the protein or in processing of the precursor (Fig 1C). These results led us to produce various $\mathrm{His}_{6}$ tagged forms of mouse and human GDF9 to enable the purification of these proteins and the characterization of the bioactivity of the human protein (Fig 1B). The constructs differ only in the location of the $\mathrm{His}_{6}$ epitope tag, fused to the carboxy terminus of the protein in the case of C6H GDF9, and near the amino terminus of the processed mature region in the case of $\mathrm{N6H}$ GDF9 (inserted between the $4^{\text {th }}$ and $5^{\text {th }}$ amino acids of the mature region to minimize problems in processing (Wolfraim et al. 2002)). The different recombinant proteins derived from the expression constructs shown in Fig. 1B were produced in stable HEK-293T cell lines. The various forms of recombinant GDF9 can be detected in medium conditioned by these cell lines utilizing the monoclonal antibody $\mathrm{mAb}-53$, which is specific for an epitope conserved within the mammalian GDF9 proteins (Gilchrist et al. 2004b). The $\mathrm{His}_{6}$ tagged forms of mouse and human GDF9 were expressed and processed similarly to the wild type proteins when produced by HEK-293T cells (Fig. 1C).

\section{C-terminally tagged mouse and human GDF9 are inactive}

The placement of a $\mathrm{His}_{6}$ tag at the C-terminus of the mouse and human mature regions of GDF9 enabled the purification of these proteins via $\mathrm{Ni2}+$ based IMAC chromatography (Fig 2A-C). Bioactivity of the conditioned media and the purified GDF9 mature regions was assayed on primary cultures of hGL cells (Kaivo-Oja et al. 2005). The hGL cells were treated with either purified mouse (Fig. 2D) or human (Fig. 2E \& F)
GDF9 $\mathrm{C} 6 \mathrm{H}$, or with untagged mouse GDF9 conditioned medium as a control. Both mouse and human GDF9 were inactive as the purified $\mathrm{C} 6 \mathrm{H}$ tagged forms. We found that although wild type mGDF9 is produced in a bioactive form, the bioactivity is lost when a $\mathrm{His}_{6}$ tag is placed at the $\mathrm{C}$-terminus of the mature region, demonstrated by the lack of bioactivity of conditioned medium containing mGDF9 C6H (Fig. 2D). Furthermore, human GDF9 $\mathrm{C} 6 \mathrm{H}$ was additionally purified via high performance liquid chromatography (HPLC) (Fig. 2C) resulting in the removal of higher molecular weight impurities. However, the purified hGDF9 $\mathrm{C} 6 \mathrm{H}$ still did not exhibit detectable bioactivity (Fig. 2F).

\section{$N$-terminally tagged mature mouse GDF9 is active}

Since the addition of a $\mathrm{His}_{6}$-tag on the C-terminus of the mGDF9 mature region resulted in the loss of biological activity (Fig 2D), we assessed the effect of the placement of a $\mathrm{His}_{6}$-tag at the Nterminus of the mature region of GDF9. The tag was inserted between the $4^{\text {th }}$ and $5^{\text {th }}$ amino acid after the furin consensus sequence with the aim of minimizing the impact of the tag on the processing of the protein (Wolfraim et al. 2002). The N6H(4/5) mGDF9 mature region was purified by $\mathrm{Ni2}+$ based IMAC chromatography using a similar protocol to the $\mathrm{C} 6 \mathrm{H}$ tagged mouse and human GDF9 proteins (Fig. 3). A HPLC step was used to finally purify the $\mathrm{N} 6 \mathrm{H}(4 / 5)$ mGF9 mature region which appears as a single major 21 $\mathrm{kD}$ band on a silver stained SDS-PAGE gel or Western blot (Fig 3 B and D). The bioactivity of the N6H mGDF9 conditioned media was tested and it was as active as the respective wild type mGDF9 conditioned media (data not shown). The bioactivity of the partially purified (Fig 3E) and the HPLC purified (Fig 3F) N6H mGDF9 was tested on hGL cells and the protein was found to activate the Smad3 signaling pathway in a dose dependent manner. The analogous human $\mathrm{N} 6 \mathrm{H}(4 / 5)$ GDF9 protein was also produced in $293 \mathrm{~T}$ cells, and although the protein was produced and processed we were not successful in our attempts to purify the protein via $\mathrm{Ni2}+$ based IMAC (data not shown). In the case of the $\mathrm{N} 6 \mathrm{H}(4 / 5)$ hGDF9 protein, the N-terminal $\mathrm{His}_{6}$ tag is possibly hidden by the pro-region and not available for binding to the IMAC resin.

Purified human GDF9 activates the Smad3 signaling pathway in human ovarian granulosa 
cells, whereas the Smad1/5 signaling pathway is not activated.

Human untagged mature GDF9 protein produced in mammalian cells and purified to homogeneity (a gift from BioTechVisions, Ltd.) appears in silver staining (Fig. 4A) and Western blotting (Fig. 4B) as a major single $21 \mathrm{kD}$ band representing the pure mature region of hGDF9. The purified hGDF9 activated the Smad3 signaling pathway in hGL cells in a dose dependent manner (Fig. 4C), similarly as we have previously reported for unpurified mGDF9 (Kaivo-Oja et al. 2005). As the hGL cells have undergone a process of terminal differentiation in response to a luteinizing surge of gonadotropins, we wanted to further characterize the purified human GDF9 on granulosa cells which have not become terminally differentiated. The human granulosa tumor cell line KGN was chosen as it is FSH responsive and as such has been used as a model system for human granulosa cell responses (Nishi et al. 2001). It can be seen in Figure 4D that the KGN cell line responds to purified human GDF9, as measured via Smad3 activation, in a similar manner as the hGL cells (Fig 4C). Since we observed activation of the Smad3 pathway by purified hGDF9 in human ovarian granulosa cells, we wanted to determine whether the protein would also activate the BMP signaling pathway (Smad 1/5) in such cells. As hGL cells are refractory to transfection by liposome-based reagents (Bondestam et al. 2002) we made an adenovirus incorporating the BRE-luciferase reporter and used adenoviral gene transduction to test various ligands in an analogous manner as with the adenoviral CAGA-luciferase reporter (Fig. 4C). BMP2 activated the BRE-luciferase reporter in human granulosa-luteal cells whereas TGF $\beta$, activin A or purified hGDF9 did not (Fig. 4E). Further, the same result was obtained in the KGN cell line, BMP2 stimulating the BREluciferase reporter (introduced in this case as a plasmid via liposome based transfection), whereas TGF $\beta$, activin A or purified hGDF9 did not (Fig. 4F). The lack of activation of the BRE-luciferase reporter in human ovarian granulosa cells demonstrates that although hGDF9 uses a hybrid of the TGF $\beta$ /Activin and BMP pathways at the receptor level, the downstream signaling events are mediated by the TGF $\beta /$ Activin $(\operatorname{Smad} 2 / 3)$ pathway.

\section{Purified human GDF9 stimulates rat granulosa cell $\left.\Gamma^{3} \mathrm{H}\right]$-thymidine incorporation}

The effects of the purified $\mathrm{C} 6 \mathrm{H}$ tagged and untagged forms of hGDF9 on rat granulosa cell DNA synthesis as monitored by $\left[{ }^{3} \mathrm{H}\right]$-thymidine incorporation were tested. Both unpurified mGDF9 and purified hGDF9 were potent stimulators of rat granulosa cell DNA synthesis (Fig. 5A \& B) with increased $(\mathrm{P}<0.05)\left[{ }^{3} \mathrm{H}\right]$ thymidine incorporation observed at doses $\geq 100$ $\mathrm{ng} / \mathrm{ml}$ for both unpurified mGDF9 and purified untagged hGDF9. The purified $\mathrm{C6H}$ tagged hGDF9 protein was completely inactive in the rat granulosa cell $\left[{ }^{3} \mathrm{H}\right]$-thymidine incorporation assay (Fig. 5C), clearly demonstrating that the stimulation of DNA synthesis by the purified hGDF9 sample (Fig. 5B) was due to the presence of the hGDF9 protein.

\section{Discussion}

It is now well established that during folliculogenesis there is a dynamic interplay between the oocyte and the surrounding somatic cells that mutually influences growth and differentiation of the somatic granulosa cells and the oocyte, and is essential for normal fertility (Eppig 2001; Gilchrist et al. 2004a). Studies using mice (Dong et al. 1996; Carabatsos et al. 1998) and sheep (Galloway et al. 2000; Juengel et al. 2002; Hanrahan et al. 2004; Bodin et al. 2006; McNatty et al. 2006) with inactivating mutations in the GDF9 gene or involving peptide immunizations for either GDF9 or GDF9B have revealed important roles for these oocyte growth factors in the stimulation of early follicular growth and fertility. However, little has been known about the role of GDF9 in regulating fertility in humans. We have previously studied GDF9 signaling with HEK-293T cell produced mGDF9 and shown that this protein activates the Smad 2/3 pathway in various granulosa cells. The mGDF9 protein does not require any purification steps to reveal the Smad activation activity. In contrast, we show in the present study that hGDF9, which is $90 \%$ identical to mGDF9 in the mature portion of the molecule, is produced by HEK-293T cells in an inactive form needing purification before the bioactivity of the protein can be detected. Although the reason for this species specific difference between recombinant mouse and human GDF9 is not yet clear, we have shown in the current study by SDS-PAGE immunoblotting that this lack of bioactivity in the case of hGDF9 is not due to a problem in the 
production of the protein or in processing of the precursor in HEK-293T cells.

The main purpose of this study was to produce and purify biologically active human GDF9, and to achieve this aim we chose to utilize the $\mathrm{His}_{6} \mathrm{tag}$ which enables the purification of the tagged protein via $\mathrm{Ni}^{2+}$ based IMAC chromatography. We report that the position of the affinity purification tag crucially effects GDF9 bioactivity. We initially placed the $\mathrm{His}_{6}$ tag at the carboxy terminus of both the mouse and human GDF9 proteins. This resulted in the loss of biological activity in the case of mGDF9 $\mathrm{C} 6 \mathrm{H}$ conditioned media, and likewise the purified form of the C6H tagged mGDF9 was inactive. As is the case for the unpurified human GDF9wt form, the $\mathrm{C} 6 \mathrm{H}$ tagged human GDF9 conditioned media and the purified protein were inactive. Next, the $\mathrm{His}_{6}$ tag was placed at the amino terminus of the mouse and human GDF9 mature regions. The tag was inserted between the $4^{\text {th }}$ and $5^{\text {th }}$ amino acid after the furin consensus sequence with the aim of minimizing the impact of the tag on the processing of the protein (Wolfraim et al. 2002). The N6H(4/5) mGDF9 conditioned media and the purified form of the protein was active whereas the analogous human N6H(4/5) GDF9 protein was inactive in conditioned media, as is the unmodified human protein. A previous study by Hayashi et al (Hayashi et al. 1999) demonstrated that the wild type form of recombinant rat GDF9 is capable of stimulating the development of cultured early ovarian follicles, whereas the stimulatory effects can not be achieved with amino terminally tagged rat GDF9, which is apparently not bioactive. However, in the case of Hayashi et al the tag fused to the N-terminus of the rat GDF9 mature region consisted of both the Flag and $\mathrm{His}_{6}$ tags, and hence is substantially longer than a $\mathrm{His}_{6}$ tag alone, presumably accounting for the difference between our study and this previous one. In our experience the Nterminus of the hGDF9 mature region is not a suitable place to insert the $\mathrm{His}_{6}$ tag since we were not successful in our attempts to purify the protein via $\mathrm{Ni}^{2+}$ based IMAC. It is possible that the $\mathrm{His}_{6}$ tag of the human N6H(4/5) GDF9 protein is obscured by the pro-region and the tag is not available for binding to the IMAC resin.

During this study the purified untagged mature region of hGDF9 became available to us and hence we tested the protein in transcriptional reporter assays specific for $S m a d 3 / 4$ activation in human ovarian granulosa cells. The purified human GDF9 mature region activated Smad3 in both our human granulosa cell models, i.e. hGL and KGN cells. KGN cells are a FSH responsive human granulosa tumor cell line (Nishi et al. 2001), hence the activation of Smad3 in these cells by hGDF9 demonstrates that the similar bioactivity observed in hGL cells is not an artifact of luteinization. No Smad 1/5 activation (characteristic of the BMP signaling pathway) was detected in either hGL or KGN cells after treatment with hGDF9, indicating that the biological activity of hGDF9 is restricted to activation of the TGF- $\beta$ /activin signaling pathway. To give our results a broader relevance we studied the effect of hGDF9 on granulosa cell proliferation in primary rat granulosa cell cultures. The ability of unpurified rodent GDF9 to act on granulosa cell proliferation has been studied (Gilchrist et al. 2001; Gilchrist et al. 2004a; Gilchrist et al. 2004b; Hickey et al. 2005; Gilchrist et al. 2006), and consistent with previous results we find that purified human GDF9 is a potent stimulator of mitogenesis in rat granulosa cells. The effect of a C-terminal epitope tag on the ability of hGDF9 to induce granulosa cell mitogenesis was clear. The HPLC purified $\mathrm{C} 6 \mathrm{H}$ hGDF9 was not able to activate Smad3 and it did not have significant mitogenic activity. We tested if the purified $\mathrm{C} 6 \mathrm{H}$ hGDF9 would be antagonising the bioactivity of the purified hGDF9, but no effect was seen (data not shown). Recently Gilchrist et al (Gilchrist et al. 2006) demonstrated by using mural oocyte-granulosa cell co-cultures that oocyte paracrine factors primarily utilize a similar signaling pathway (TGF $\beta /$ Activin) to that used by GDF9 for transmitting their mitogenic actions on granulosa cells. As the $\mathrm{C} 6 \mathrm{H}$ tag on the hGDF9 protein impairs its ability to signal through Smad3, it is not surprising that it does not induce mitogenesis in ovarian granulosa cells.

In conclusion, the present study demonstrates that the hGDF9 protein is produced in a latent form and that upon purification the ability of the hGDF9 mature protein to activate the Smad3 pathway is revealed. The Smad3 pathway has been shown to be relevant for oocyte controlled granulosa cell mitogenesis and here we also demonstrate that primary cultures of rat granulosa cells responded to purified hGDF9 with an increase in DNA synthesis as measured by $\left[{ }^{3} \mathrm{H}\right]$ thymidine uptake, indicating that hGDF9 is mitogenic. This first characterization of purified biologically active human GDF9 is of importance 
for studies on human fertility, and efforts aimed at treating infertility conditions. Understanding the molecular mechanisms behind the activation of the hGDF9 latent form will help clarify its functions in the ovary and the availability of purified bioactive hGDF9 will now enable detailed binding studies to characterise cell surface bound and soluble GDF9 binding proteins. 


\section{Acknowledgements}

The skillful technical assistance of Ms. Marjo Rissanen and Mr. Jarmo Koponen is kindly acknowledged. The personnel of the Family Federation of Finland are kindly acknowledged for their assistance. We thank Dr. C. H. Heldin (Ludwig Institute for Cancer Research, Uppsala, Sweden) for the CAGA promoter-luciferase construct.

The work of the Ritvos laboratory was supported by grants from the Academy of Finland, the
Finnish National Technology Agency, the Juselius Foundation, the Jalmari and Rauha Ahokas Foundation, the Novo Nordisk Foundation, the Center for International Mobility, Helsinki University research funds, and Helsinki University Central Hospital funds. The work of the AgResearch Laboratory at Wallaceville Animal Research Centre was supported by the New Zealand Foundation for Research Science and Technology and Ovita Ltd., Dunedin, New Zealand. 


\section{References}

Bodin, L., E. Di Pasquale, S. Fabre, M. Bontoux, P. Monget, L. Persani and P. Mulsant 2006. A novel mutation in the BMP15 gene causing defective protein secretion is associated with both increased ovulation rate and sterility in Lacaune sheep. Endocrinology.

Bondestam, J., N. Kaivo-oja, J. Kallio, N. Groome, C. Hyden-Granskog, M. Fujii, A. Moustakas, A. Jalanko, P. ten Dijke and O. Ritvos 2002. Engagement of activin and bone morphogenetic protein signaling pathway Smad proteins in the induction of inhibin B production in ovarian granulosa cells. Mol Cell Endocrinol 195(1-2): 79-88.

Carabatsos, M. J., J. Elvin, M. M. Matzuk and D. F. Albertini 1998. Characterization of oocyte and follicle development in growth differentiation factor-9-deficient mice. Dev Biol 204(2): 373-84.

Dennler, S., S. Itoh, D. Vivien, P. ten Dijke, S. Huet and J. M. Gauthier 1998. Direct binding of Smad3 and Smad4 to critical TGF beta-inducible elements in the promoter of human plasminogen activator inhibitor-type 1 gene. Embo J 17(11): 3091-100.

Dixit, H., L. K. Rao, V. Padmalatha, M. Kanakavalli, M. Deenadayal, N. Gupta, B. Chakravarty and L. Singh 2005. Mutational screening of the coding region of growth differentiation factor 9 gene in Indian women with ovarian failure. Menopause 12(6): 749-54.

Dong, J., D. F. Albertini, K. Nishimori, T. R. Kumar, N. Lu and M. M. Matzuk 1996. Growth differentiation factor-9 is required during early ovarian folliculogenesis. Nature 383(6600): 531-5.

Dooley, S., J. Hamzavi, K. Breitkopf, E. Wiercinska, H. M. Said, J. Lorenzen, P. Ten Dijke and A. M. Gressner 2003. Smad7 prevents activation of hepatic stellate cells and liver fibrosis in rats. Gastroenterology 125(1): 178-91.

Elvin, J. A., C. Yan, P. Wang, K. Nishimori and M. M. Matzuk 1999. Molecular characterization of the follicle defects in the growth differentiation factor 9-deficient ovary. Mol Endocrinol 13(6): 1018-34.

Eppig, J. J. 2001. Oocyte control of ovarian follicular development and function in mammals. Reproduction 122(6): 829-38.

Eramaa, M., K. Heikinheimo, T. Tuuri, K. Hilden and O. Ritvos 1993. Inhibin/activin subunit mRNA expression in human granulosa-luteal cells. Mol Cell Endocrinol 92(2): R15-20.

Galloway, S. M., K. P. McNatty, L. M. Cambridge, M. P. Laitinen, J. L. Juengel, T. S. Jokiranta, R. J. McLaren, K. Luiro, K. G. Dodds, G. W. Montgomery, A. E. Beattie, G. H. Davis and O. Ritvos 2000. Mutations in an oocyte-derived growth factor gene (BMP15) cause increased ovulation rate and infertility in a dosage-sensitive manner. Nat Genet 25(3): 279-83.

Gilchrist, R. B., L. J. Ritter and D. T. Armstrong 2001. Mouse oocyte mitogenic activity is developmentally coordinated throughout folliculogenesis and meiotic maturation. Developmental Biology 240(1): 289-98.

Gilchrist, R. B., L. J. Ritter and D. T. Armstrong 2004a. Oocyte-somatic cell interactions during follicle development in mammals. Anim Reprod Sci 82-83: 431-46.

Gilchrist, R. B., L. J. Ritter, M. Cranfield, L. A. Jeffery, F. Amato, S. J. Scott, S. Myllymaa, N. Kaivo-Oja, H. Lankinen, D. G. Mottershead, N. P. Groome and O. Ritvos 2004b. Immunoneutralization of growth differentiation factor 9 reveals it partially accounts for mouse oocyte mitogenic activity. Biol Reprod 71(3): 732-9.

Gilchrist, R. B., L. J. Ritter, S. Myllymaa, N. Kaivo-Oja, R. A. Dragovic, T. E. Hickey, O. Ritvos and D. G. Mottershead 2006. Molecular basis of oocyte-paracrine signalling that promotes granulosa cell proliferation. J Cell Sci 119(Pt 18): 3811-21.

Hanrahan, J. P., S. M. Gregan, P. Mulsant, M. Mullen, G. H. Davis, R. Powell and S. M. Galloway 2004. Mutations in the genes for oocyte-derived growth factors GDF9 and BMP15 are associated with both increased ovulation rate and sterility in Cambridge and Belclare sheep (Ovis aries). Biol Reprod 70(4): 900-9. 
Hayashi, M., E. A. McGee, G. Min, C. Klein, U. M. Rose, M. van Duin and A. J. Hsueh 1999. Recombinant growth differentiation factor-9 (GDF-9) enhances growth and differentiation of cultured early ovarian follicles. Endocrinology 140(3): 1236-44.

He, T. C., S. Zhou, L. T. da Costa, J. Yu, K. W. Kinzler and B. Vogelstein 1998. A simplified system for generating recombinant adenoviruses. Proc Natl Acad Sci U S A 95(5): 2509-14.

Hickey, T. E., D. L. Marrocco, F. Amato, L. J. Ritter, R. J. Norman, R. B. Gilchrist and D. T. Armstrong 2005. Androgens augment the mitogenic effects of oocyte-secreted factors and growth differentiation factor 9 on porcine granulosa cells. Biol Reprod 73(4): 825-32.

Hobbs, S., S. Jitrapakdee and J. C. Wallace 1998. Development of a bicistronic vector driven by the human polypeptide chain elongation factor 1alpha promoter for creation of stable mammalian cell lines that express very high levels of recombinant proteins. Biochem Biophys Res Commun 252(2): 368-72.

Juengel, J. L., N. L. Hudson, D. A. Heath, P. Smith, K. L. Reader, S. B. Lawrence, A. R. O'Connell, M. P. Laitinen, M. Cranfield, N. P. Groome, O. Ritvos and K. P. McNatty 2002. Growth differentiation factor 9 and bone morphogenetic protein 15 are essential for ovarian follicular development in sheep. Biol Reprod 67(6): 1777-89.

Kaivo-Oja, N., J. Bondestam, M. Kamarainen, J. Koskimies, U. Vitt, M. Cranfield, K. Vuojolainen, J. P. Kallio, V. M. Olkkonen, M. Hayashi, A. Moustakas, N. P. Groome, P. ten Dijke, A. J. Hsueh and O. Ritvos 2003. Growth differentiation factor-9 induces Smad2 activation and inhibin B production in cultured human granulosa-luteal cells. J Clin Endocrinol Metab 88(2): 755-62.

Kaivo-Oja, N., D. G. Mottershead, S. Mazerbourg, S. Myllymaa, S. Duprat, R. B. Gilchrist, N. P. Groome, A. J. Hsueh and O. Ritvos 2005. Adenoviral gene transfer allows Smad-responsive gene promoter analyses and delineation of type I receptor usage of transforming growth factor-beta family ligands in cultured human granulosa luteal cells. J Clin Endocrinol Metab 90(1): 271-8.

Korchynskyi, O. and P. ten Dijke 2002. Identification and functional characterization of distinct critically important bone morphogenetic protein-specific response elements in the Id1 promoter. J Biol Chem 277(7): 4883-91.

Laissue, P., S. Christin-Maitre, P. Touraine, F. Kuttenn, O. Ritvos, K. Aittomaki, N. Bourcigaux, L. Jacquesson, P. Bouchard, R. Frydman, D. Dewailly, A. C. Reyss, L. Jeffery, A. Bachelot, N. Massin, M. Fellous and R. A. Veitia 2006. Mutations and sequence variants in GDF9 and BMP15 in patients with premature ovarian failure. Eur J Endocrinol 154(5): 739-44.

Laitinen, M., K. Vuojolainen, R. Jaatinen, I. Ketola, J. Aaltonen, E. Lehtonen, M. Heikinheimo and O. Ritvos 1998. A novel growth differentiation factor-9 (GDF-9) related factor is coexpressed with GDF-9 in mouse oocytes during folliculogenesis. Mech Dev 78(1-2): 13540.

Mazerbourg, S., C. Klein, J. Roh, N. Kaivo-Oja, D. G. Mottershead, O. Korchynskyi, O. Ritvos and A. J. Hsueh 2004. Growth differentiation factor-9 signaling is mediated by the type I receptor, activin receptor-like kinase 5. Mol Endocrinol 18(3): 653-65.

McGrath, S. A., A. F. Esquela and S. J. Lee 1995. Oocyte-specific expression of growth/differentiation factor-9. Mol Endocrinol 9(1): 131-6.

McNatty, K. P., N. L. Hudson, L. Whiting, K. L. Reader, S. Lun, A. Western, D. A. Heath, P. Smith, L. G. Moore and J. L. Juengel 2006. The Effects of Immunizing Sheep with Different BMP15 or GDF9 Peptide Sequences on Ovarian Follicular Activity and Ovulation Rate. Biol Reprod.

McNatty, K. P., J. L. Juengel, K. L. Reader, S. Lun, S. Myllymaa, S. B. Lawrence, A. Western, M. F. Meerasahib, D. G. Mottershead, N. P. Groome, O. Ritvos and M. P. Laitinen 2005. Bone morphogenetic protein 15 and growth differentiation factor 9 co-operate to regulate granulosa cell function in ruminants. Reproduction 129(4): 481-7. 
McPherron, A. C. and S. J. Lee 1993. GDF-3 and GDF-9: two new members of the transforming growth factor-beta superfamily containing a novel pattern of cysteines. J Biol Chem 268(5): 3444-9.

Montgomery, G. W., Z. Z. Zhao, A. J. Marsh, R. Mayne, S. A. Treloar, M. James, N. G. Martin, D. I. Boomsma and D. L. Duffy 2004. A deletion mutation in GDF9 in sisters with spontaneous DZ twins. Twin Res 7(6): 548-55.

Nishi, Y., T. Yanase, Y. Mu, K. Oba, I. Ichino, M. Saito, M. Nomura, C. Mukasa, T. Okabe, K. Goto, R. Takayanagi, Y. Kashimura, M. Haji and H. Nawata 2001. Establishment and characterization of a steroidogenic human granulosa-like tumor cell line, KGN, that expresses functional follicle-stimulating hormone receptor. Endocrinology 142(1): 437-45.

Palmer, J. S., Z. Z. Zhao, C. Hoekstra, N. K. Hayward, P. M. Webb, D. C. Whiteman, N. G. Martin, D. I. Boomsma, D. L. Duffy and G. W. Montgomery 2006. Novel variants in growth differentiation factor 9 in mothers of dizygotic twins. J Clin Endocrinol Metab 91(11): 4713-6.

Roh, J. S., J. Bondestam, S. Mazerbourg, N. Kaivo-Oja, N. Groome, O. Ritvos and A. J. Hsueh 2003. Growth differentiation factor-9 stimulates inhibin production and activates Smad2 in cultured rat granulosa cells. Endocrinology 144(1): 172-8.

Teixeira Filho, F. L., E. C. Baracat, T. H. Lee, C. S. Suh, M. Matsui, R. J. Chang, S. Shimasaki and G. F. Erickson 2002. Aberrant expression of growth differentiation factor-9 in oocytes of women with polycystic ovary syndrome. J Clin Endocrinol Metab 87(3): 1337-44.

Vitt, U. A., S. Mazerbourg, C. Klein and A. J. Hsueh 2002. Bone morphogenetic protein receptor type II is a receptor for growth differentiation factor-9. Biol Reprod 67(2): 473-80.

Wolfraim, L. A., G. M. Alkemade, B. Alex, S. Sharpe, W. T. Parks and J. J. Letterio 2002. Development and application of fully functional epitope-tagged forms of transforming growth factor-beta. J Immunol Methods 266(1-2): 7-18. 


\section{Figure legends}

Figure 1: $m G D F 9$ activates the Smad3 signaling pathway in human granulosa luteal (hGL) cells already as produced by HEK-293T cells, while hGDF9 is produced in an inactive form. A) hGL cells, transduced with an adenovirus encoding the Smad3/4 (CAGA-luc) reporter, were incubated for $24 \mathrm{~h}$ in the absence (Cont) or presence of TGFß $(3.5 \mathrm{ng} / \mathrm{ml})$, mGDF9wt conditioned medium (CM) $(170 \mathrm{ng} / \mathrm{ml})$ or hGDF9wt CM $(170 \mathrm{ng} / \mathrm{ml})$. Enzyme activity was measured in the cell extract and is expressed as fold change compared with the control (an adjusted value of 1.0 for the mean of the control wells), i.e. the activity level in the absence of ligand. The mean luciferase value of the control was 1.0 and for the hGDF9wt CM it was 2.19. B) Schematic of recombinant proteins produced in this study based on wild type and His 6 -tagged mouse or human GDF9 (SS: Signal sequence, shaded diagonal lines: Pro-region, Black: proteolytic processing site, 6H: his6-tag, shaded grey: mature region). C) Recombinant proteins produced from stable 293T cell lines were reduced with $10 \mathrm{mM}$ DTT and subjected to SDS-PAGE immunoblotting (ECL). The specific GDF9 mAb-53 (Gilchrist et al. 2004b) detects the app. $20 \mathrm{kDa}$ mature mouse and human GDF9 proteins. The $\mathrm{His}_{6}$ tagged forms of mouse and human GDF9 expressed and processed similarly to the wild type proteins when produced by HEK-293T cells.

Figure 2: Mouse and human GDF9 are inactive as the purified C6H-tagged forms. IMAC affinity chromatography purified C-terminally tagged A) mGDF9 and B) hGDF9 analyzed on a SDS-PAGE silver gel (upper) and on a Western blot (lower) probed with the GDF9 specific mAb-53. Human GDF9 C6H was additionally purified with HPLC C) and analysed on a SDS-PAGE silver gel (upper) and on a Western blot (lower). All samples were reduced with $10 \mathrm{mM}$ DTT before running into the gels $(\mathrm{In}=$ load, FT $=$ flow through, $\mathrm{U}=7 \mathrm{M}$ urea wash, $100-250=100-250 \mathrm{mM}$ successive imidazole elutions.). The bioactivity of the mature regions was tested in hGL cells. hGL cells, transduced with an adenovirus encoding the Smad3/4 (CAGA-luc) reporter, were incubated for $24 \mathrm{~h}$ in the absence (Cont) or presence of TGFß (3.5ng/ml), mGDF9wt CM, mGDF9 C6H CM, hGDF9 $\mathrm{C} 6 \mathrm{H} \mathrm{CM}$ (each at $170 \mathrm{ng} / \mathrm{ml}$ ) or in the presence of D) IMAC affinity chromatography purified mGDF9 C6H, E) IMAC affinity chromatography purified hGDF9 $\mathrm{C6H}$ or F) HPLC purified hGDF9 C6H. Enzyme activity was measured in the cell extract and is expressed as fold change compared with the control (an adjusted value of 1.0 for the mean of the control wells) i.e. the activity level in the absence of ligand. The mean luciferase values for the controls and samples with low or undetectable activity were as follows: D) Cont 0.01, mGDF9 C6H CM 0.01, AC purified mGDF9 C6H at 100 and $200 \mathrm{ng} / \mathrm{ml}, 0.01$ and 0.009, respectively; E) Cont 0.003, hGDF9 C6H CM 0.003, AC purified hGDF9 C6H at 70, 170 and $700 \mathrm{ng} / \mathrm{ml}, 0.002,0.003$ and 0.003 , respectively; F) Cont 0.50, HPLC purified hGDF9 C6H at 15, 150 and $300 \mathrm{ng} / \mathrm{ml}, 0.60,0.69$ and 0.62, respectively.

Figure 3: Purified mGDF9 N6H activates Smad3 in hGL cells in a dose dependent manner. Nterminally $\mathrm{His}_{6}$ tagged mature mGDF9 was analyzed on a SDS-PAGE silver gel A) or by Western blotting C) after IMAC affinity chromatography. The $250 \mathrm{mM}$ imidazole elution fractions were pooled and purified by high performance liquid chromatography (HPLC), the peak fraction is analyzed on a SDS-PAGE silver gel B) or by Western blotting D). All samples were reduced with $10 \mathrm{mM}$ DTT. Western blots were immunostained with GDF9 mAb-53 (L = load, FT = flow through, $\mathrm{U}=7 \mathrm{M}$ urea wash, $100-250=100-250 \mathrm{mM}$ successive imidazole elutions). hGL cells transduced with an adenovirus encoding the Smad3/4 (CAGA-luc) reporter, were incubated for $24 \mathrm{~h}$ in the absence (Cont) or presence of TGF $\beta(3.5 \mathrm{ng} / \mathrm{ml})$, mGDF9 N6H CM $(170 \mathrm{ng} / \mathrm{ml})$ or in the presence of $\mathbf{E}$ ) affinity chromatography purified mGDF9 N6H or F) HPLC purified mGDF9 N6H. The mean luciferase values for the controls were E) $0.17 \mathrm{~F}$ ) 0.53 . 
Figure 4: Purified hGDF9wt activates the Smad3 signaling pathway in ovarian granulosa cells in a dose dependent manner and the BMP signaling pathway is not activated. Purified untagged human GDF9 protein (reduced with $10 \mathrm{mM}$ DTT) analyzed on a A) SDS-PAGE silver gel and on a B) Western blot immunostained with GDF9 mAb-53. C) hGL cells transduced with an adenovirus encoding the Smad3/4 (CAGA-luc) reporter were incubated for $24 \mathrm{~h}$ in the absence (Cont) or presence of $\mathrm{mGDF} 9 \mathrm{wt} \mathrm{CM}(170 \mathrm{ng} / \mathrm{ml})$ or in the presence of various concentrations of purified hGDF9. D) KGN cells transfected with the $\mathrm{Smad} 3 / 4$ responsive (CAGA-luc) reporter were incubated for $24 \mathrm{~h}$ in the absence (Cont) or presence of TGF $\beta(3.5 \mathrm{ng} / \mathrm{ml}), \mathrm{mGDF} 9 \mathrm{wt} \mathrm{CM}$ $(200 \mathrm{ng} / \mathrm{ml})$, or in the presence of various concentrations of purified hGDF9. E) hGL cells transduced with an adenovirus encoding the Smad1/5 (BRE-luc) reporter were incubated for $24 \mathrm{~h}$ in the absence (Cont) or presence of BMP2 $(85 \mathrm{ng} / \mathrm{ml})$, TGF $\beta(3.5 \mathrm{ng} / \mathrm{ml})$, Activin A (Act, $85 \mathrm{ng} / \mathrm{ml})$ or various concentrations of purified hGDF9. F) KGN cells transfected with the Smad1/5 (BRE-luc) reporter were incubated for $24 \mathrm{~h}$ in the absence (Cont) or presence of BMP2 $(100 \mathrm{ng} / \mathrm{ml})$, TGF $\beta$ (4 $\mathrm{ng} / \mathrm{ml}$ ), Activin A (Act, $100 \mathrm{ng} / \mathrm{ml}$ ) or various concentrations of purified hGDF9. The mean luciferase values for the controls and samples with low or undetectable activity were C) Cont 0.23 ; D) Cont 0.003; E) Cont 0.01, TGF $\beta$ 0.009, Act 0.004, purified hGDF9 at 85, 170 and $340 \mathrm{ng} / \mathrm{ml}$, $0.011,0.011$ and 0.009 , respectively; F) Cont 0.002 , TGF $\beta 0.001$, Act 0.001 , purified hGDF9 at 100,200 and $400 \mathrm{ng} / \mathrm{ml}, 0.001,0.001$ and 0.001 , respectively.

Figure 5: Mouse GDF9wt CM and purified human GDF9wt stimulate rat granulosa cell [3 H]thymidine incorporation. A) mouse GDF9wt conditioned medium and B) purified human GDF9 stimulate rat ovarian granulosa cell $\left[{ }^{3} \mathrm{H}\right]$-thymidine incorporation, whereas purified human GDF9 $\mathrm{C} 6 \mathrm{H} \mathrm{C}$ ) is not active. 


\section{Figure 1}

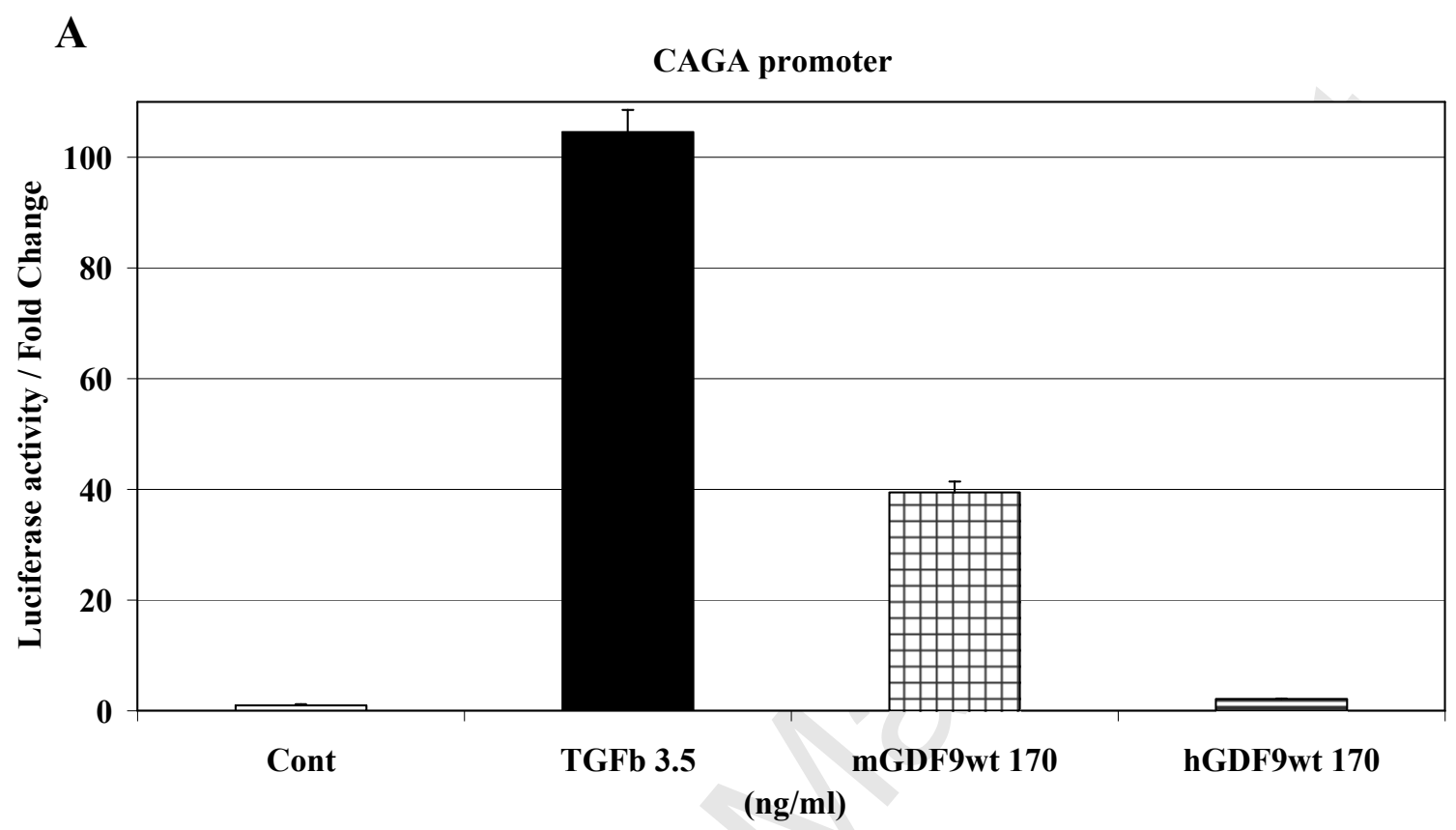

B

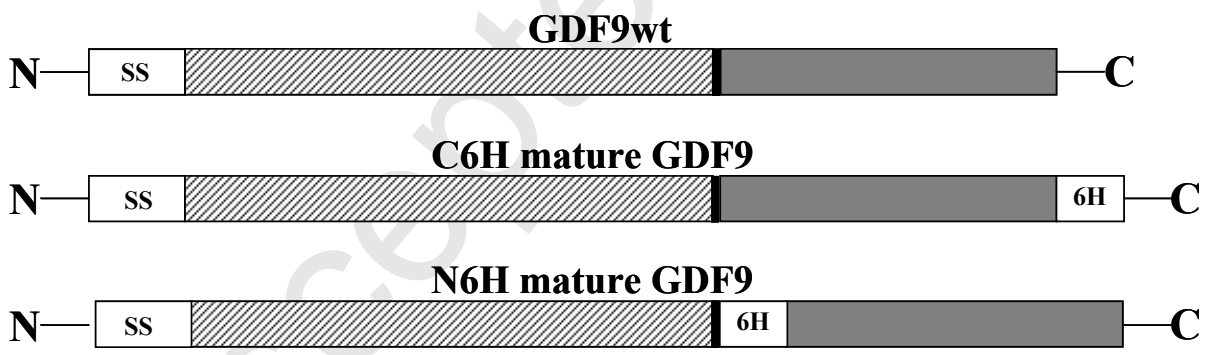

C

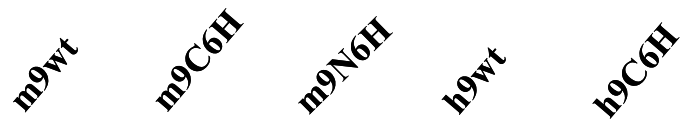

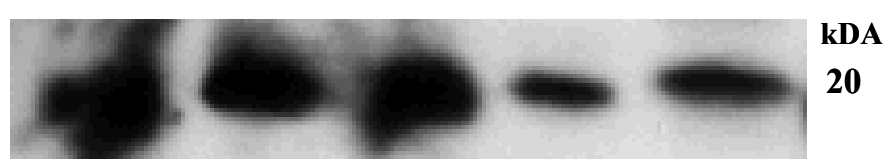




\section{Figure 2}

$\mathbf{A}$

MW In FT U $\quad 50100100250250250$

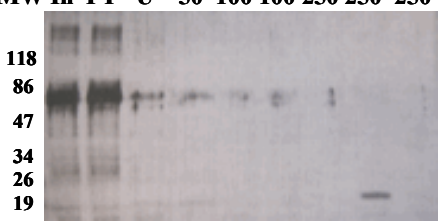

MW In FT U $50 \quad 100 \quad 100250250250$

118
86

47

34

26

19
B

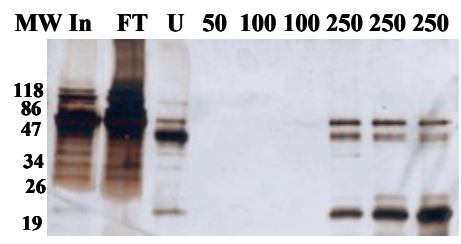

250250

118
86
47

C Fraction \#

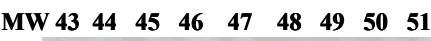

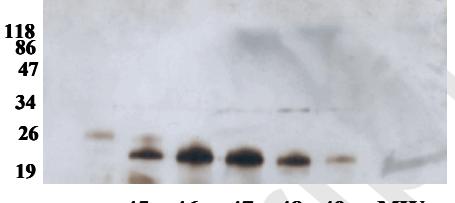

$\begin{array}{llllll}45 & 46 & 47 & 48 & 49 & M W\end{array}$

118
86

47

34

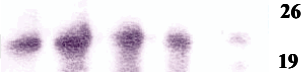


D

CAGA promoter

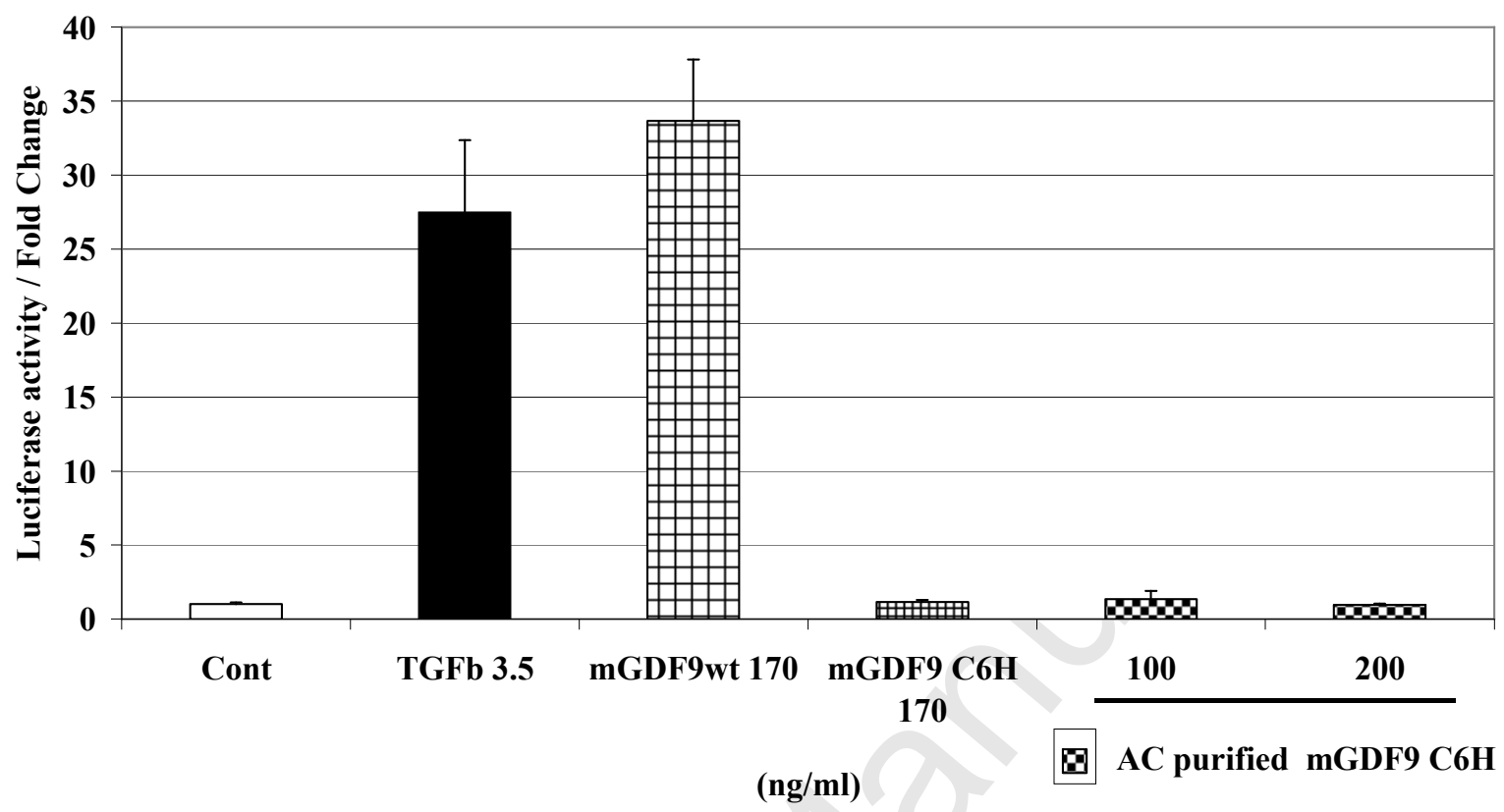

E

CAGA promoter

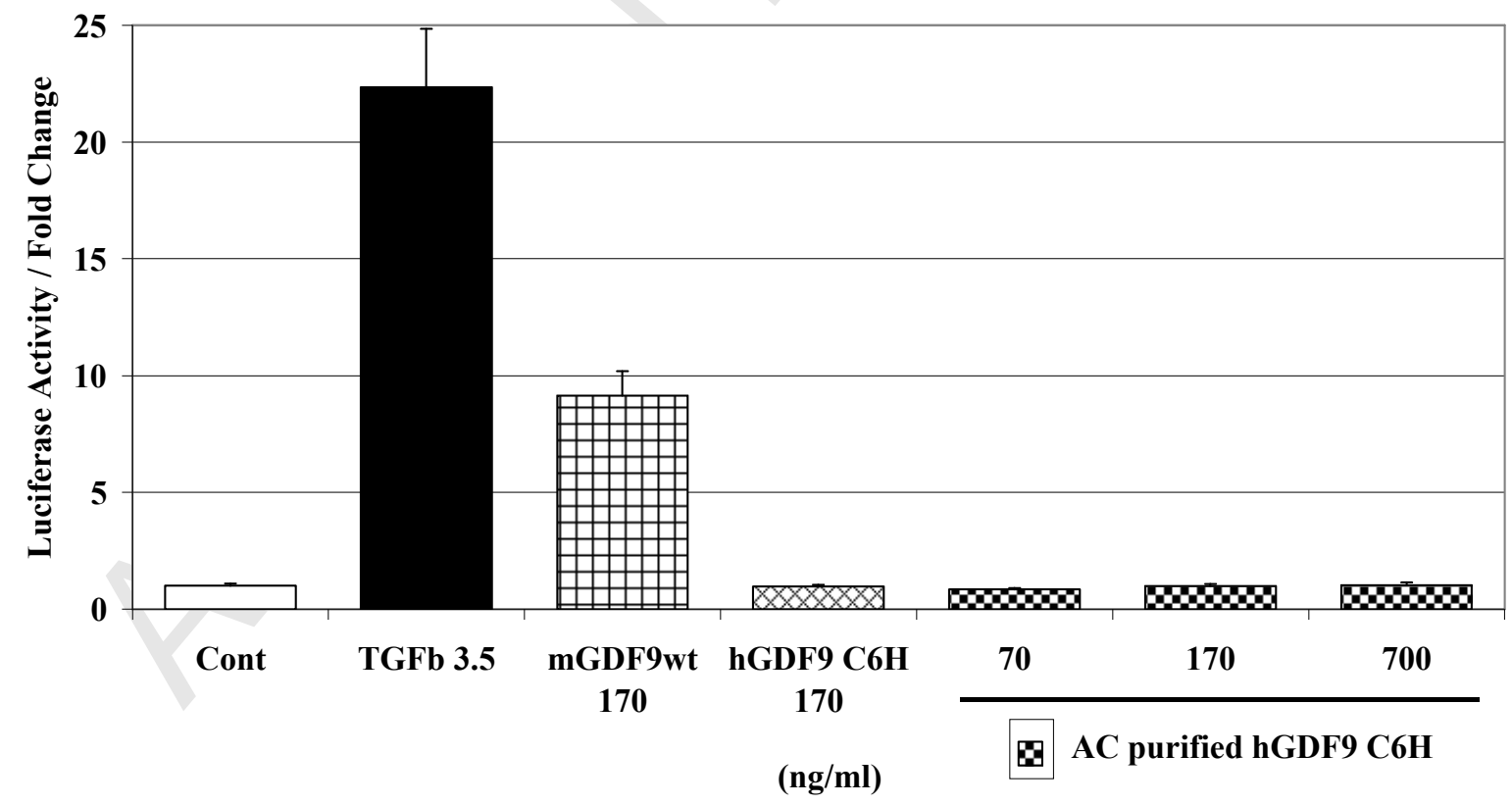




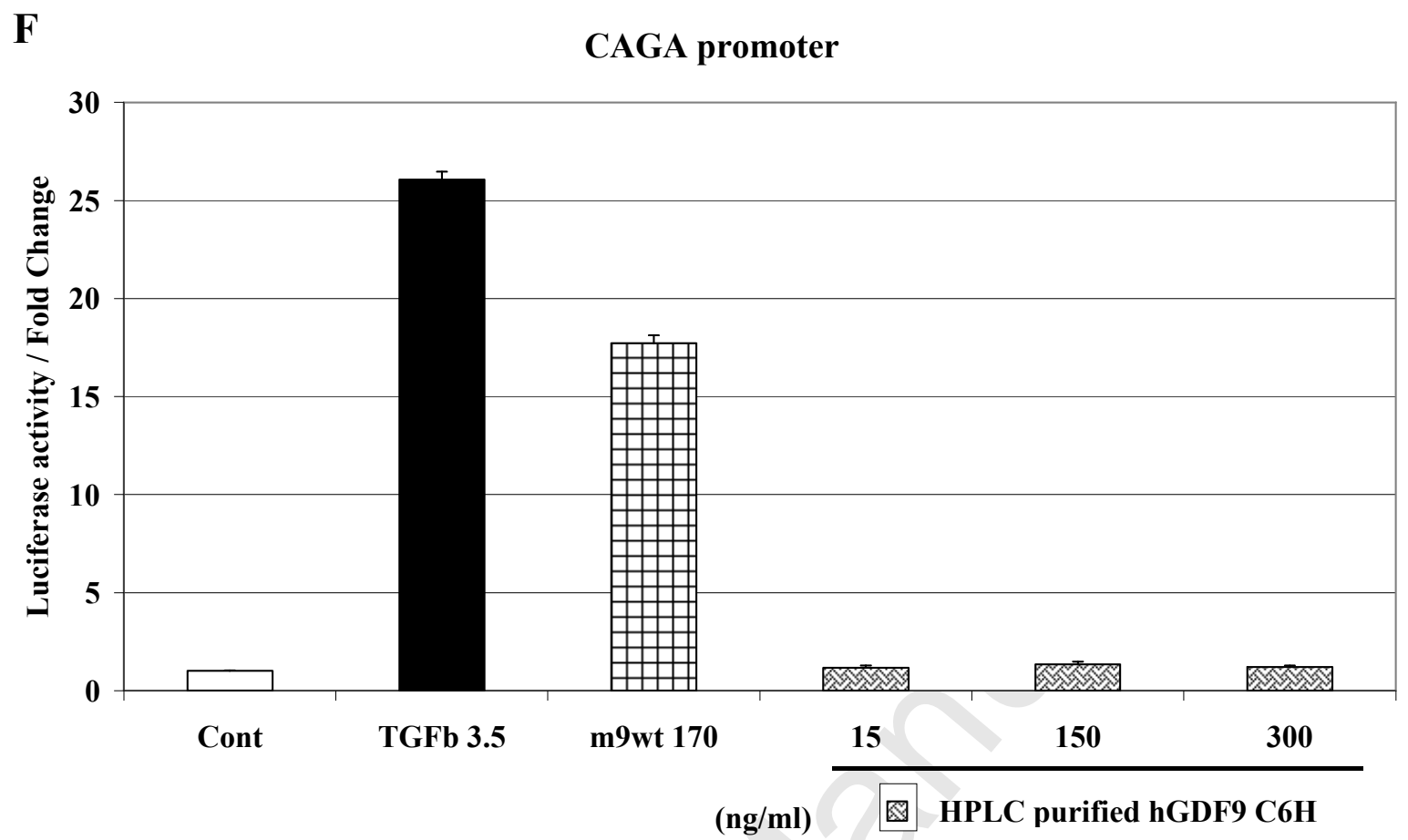




\section{Figure 3}

$\mathbf{A}$

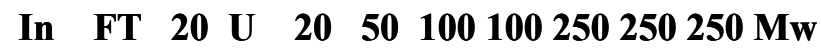

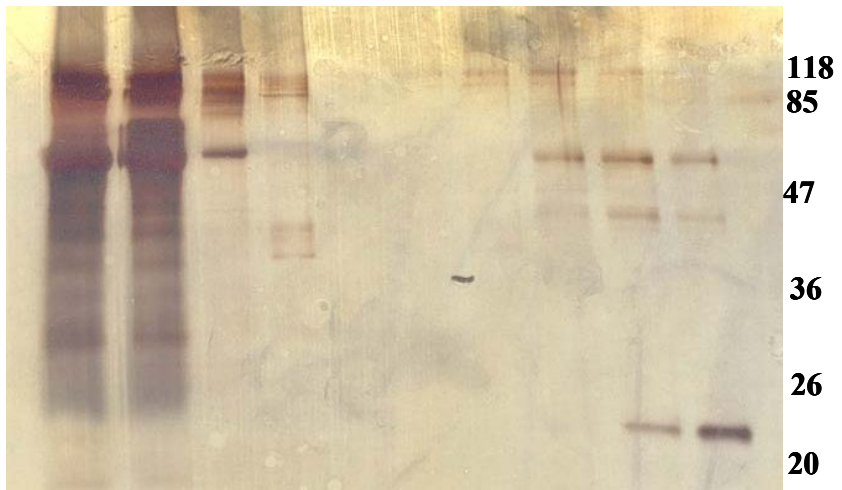

C

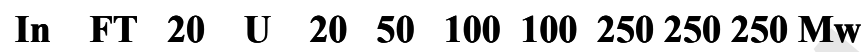

B

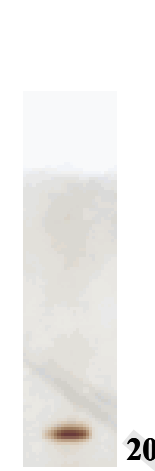

D

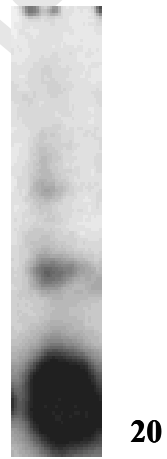


E

CAGA promoter

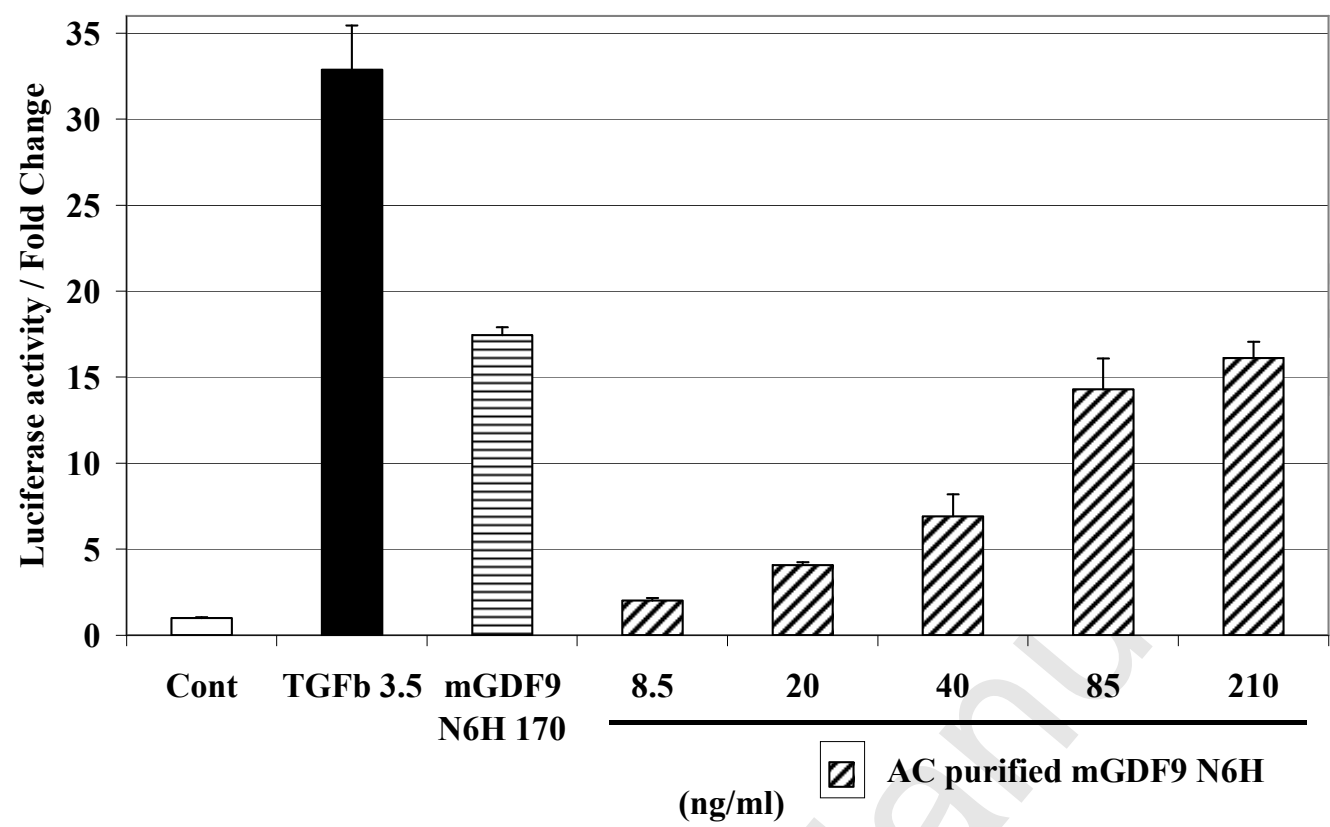

F

CAGA promoter

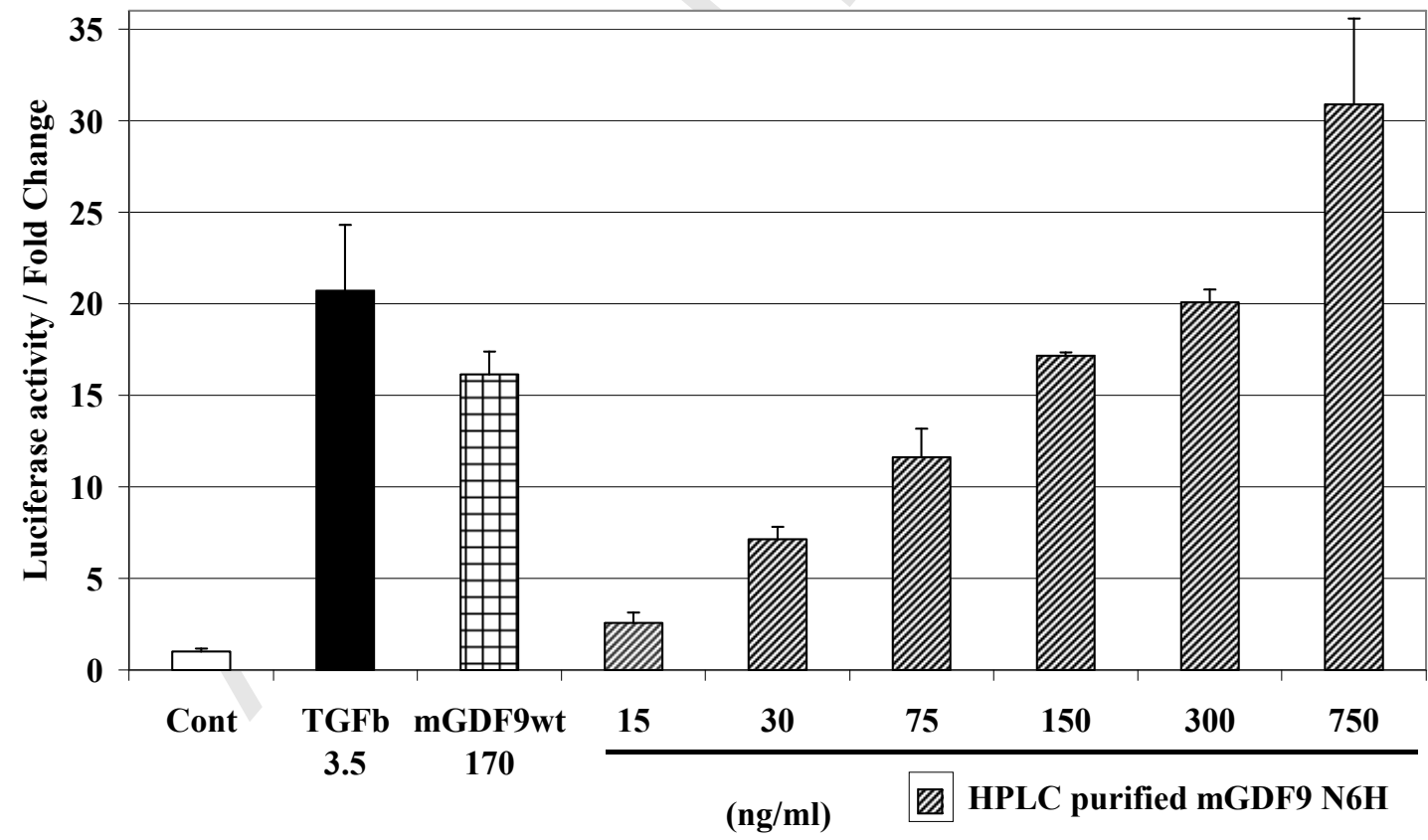




\section{Figure 4}

\begin{tabular}{|cc} 
A & B \\
\hline 118 & MW \\
85 & $\mathbf{1 1 8}$ \\
47 & 47 \\
36 & 36 \\
26 & 26 \\
20 & 20 \\
- & 5
\end{tabular}

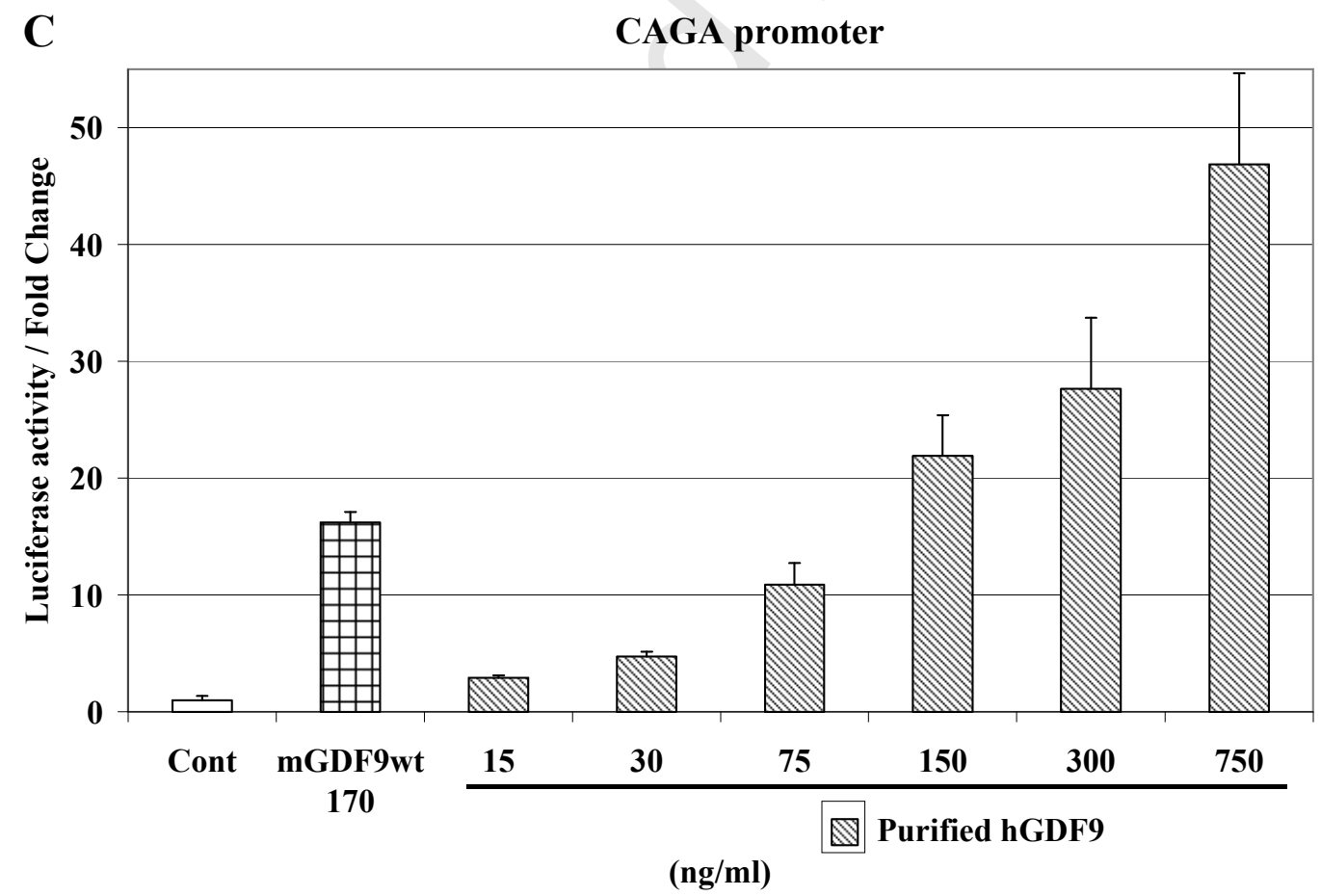



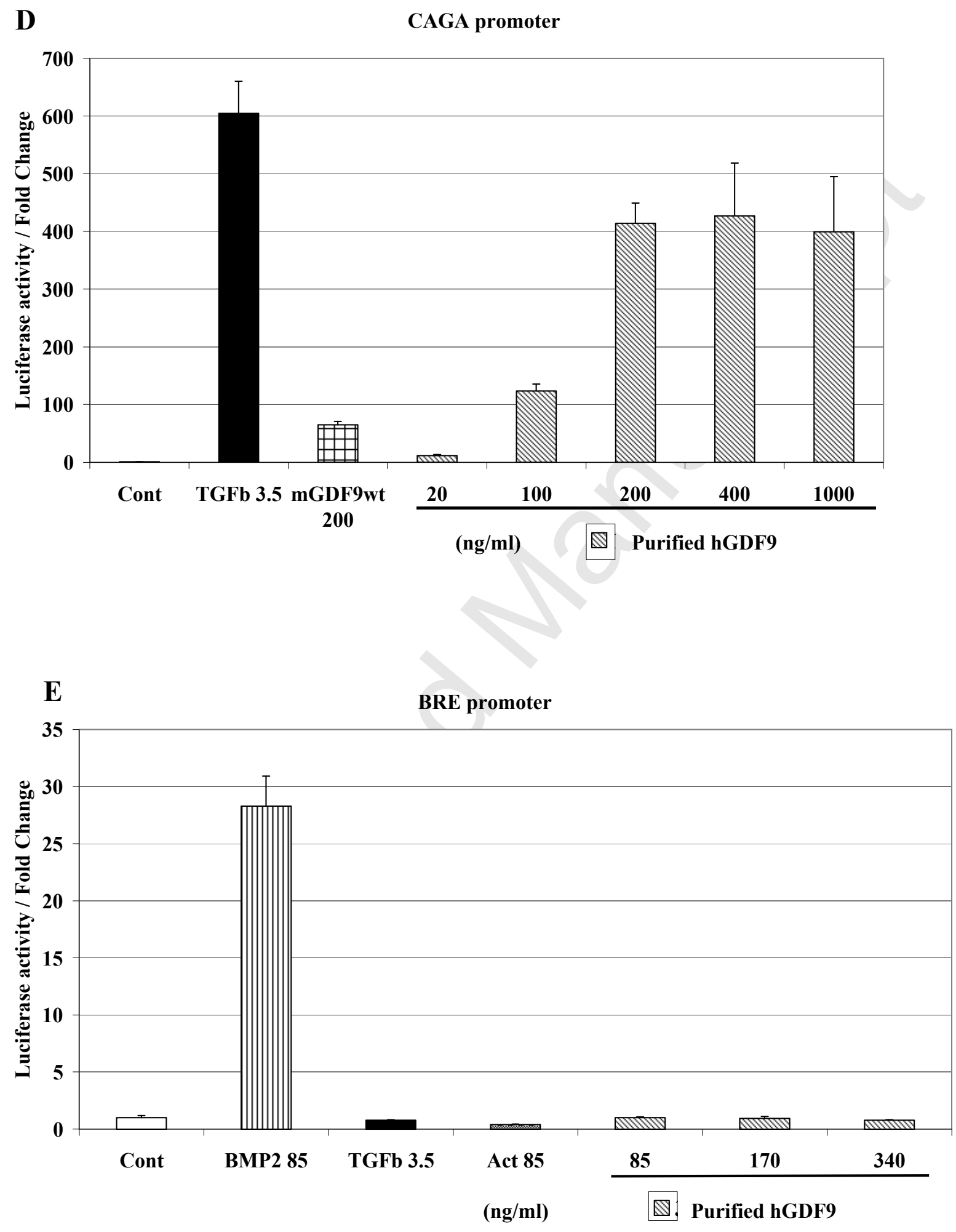


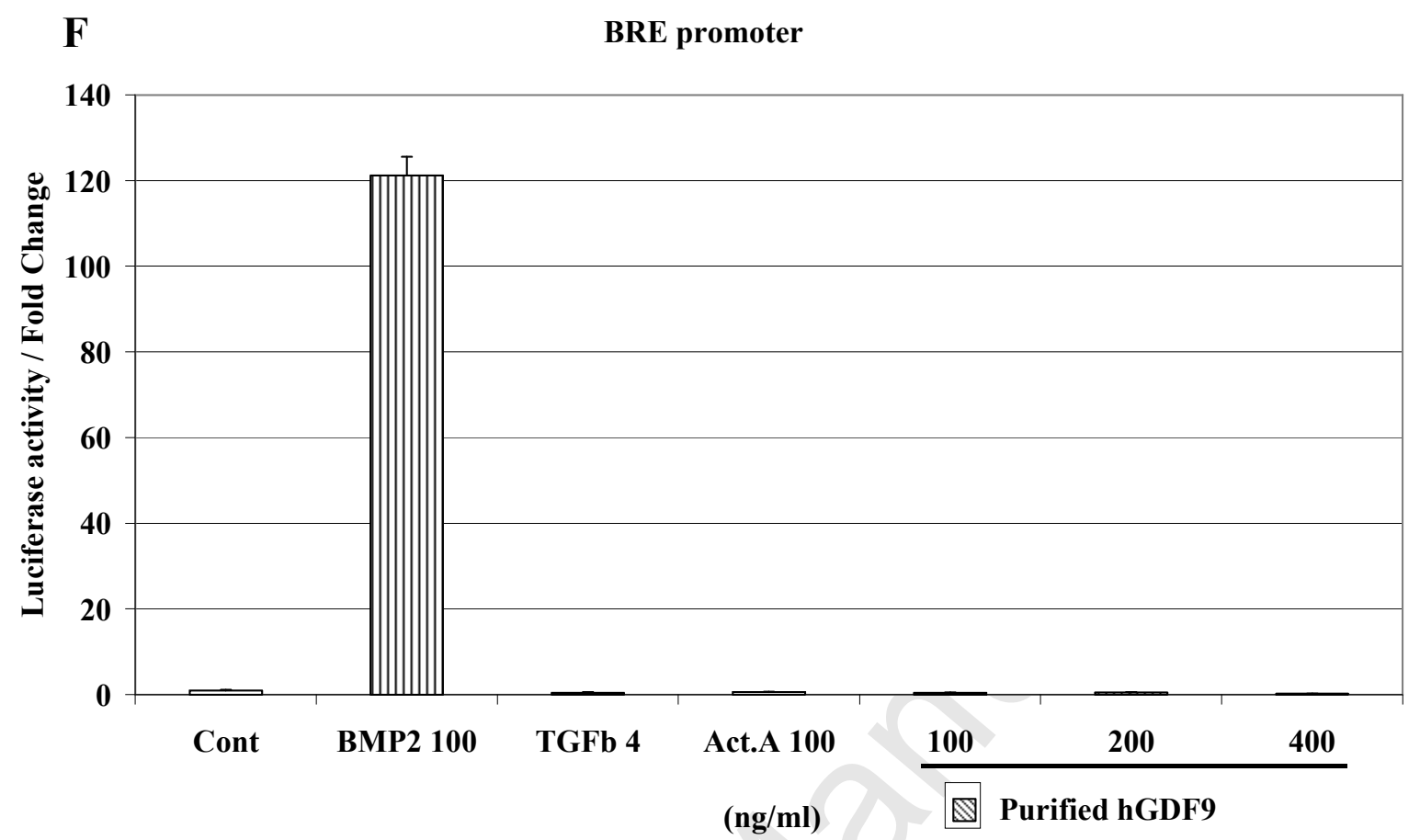




\section{Figure 5}

A

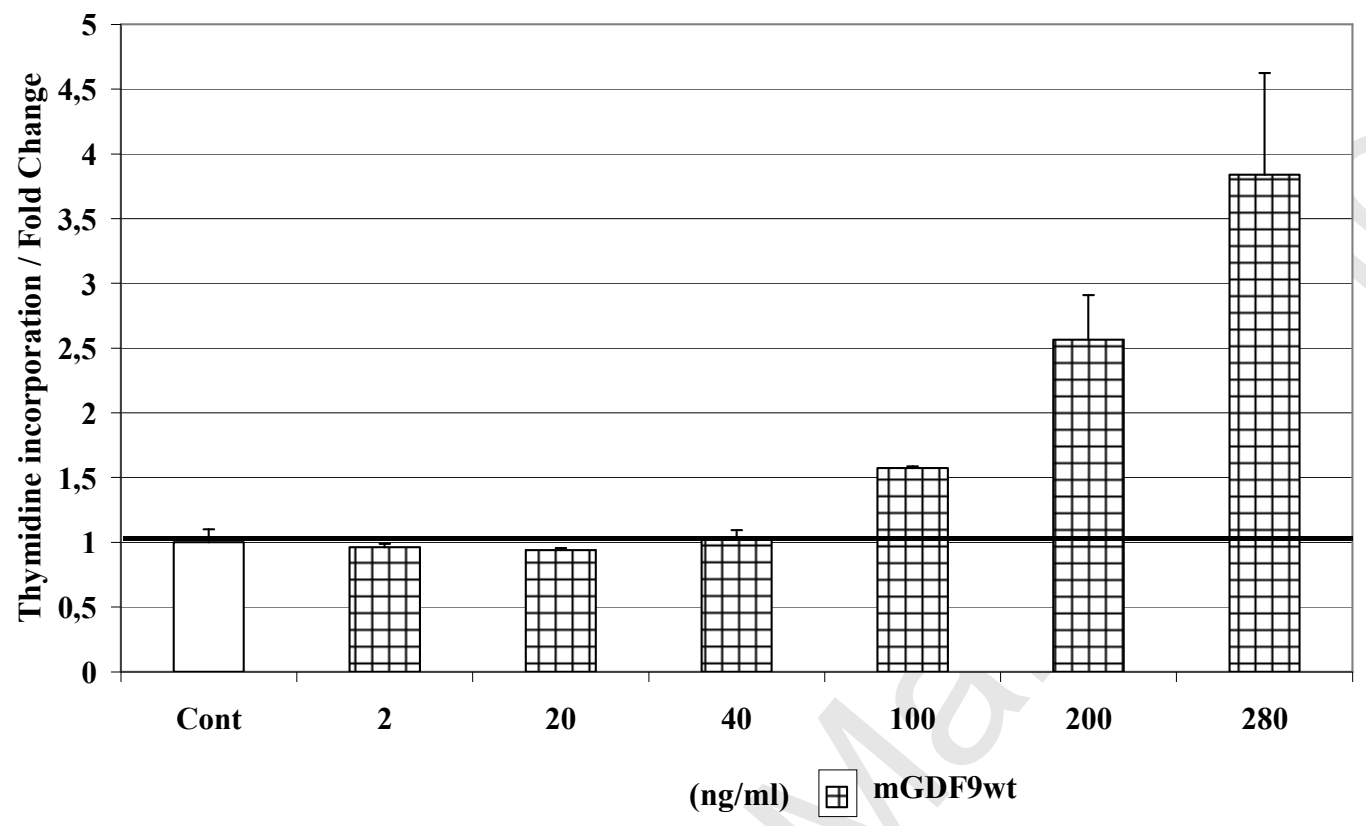

B

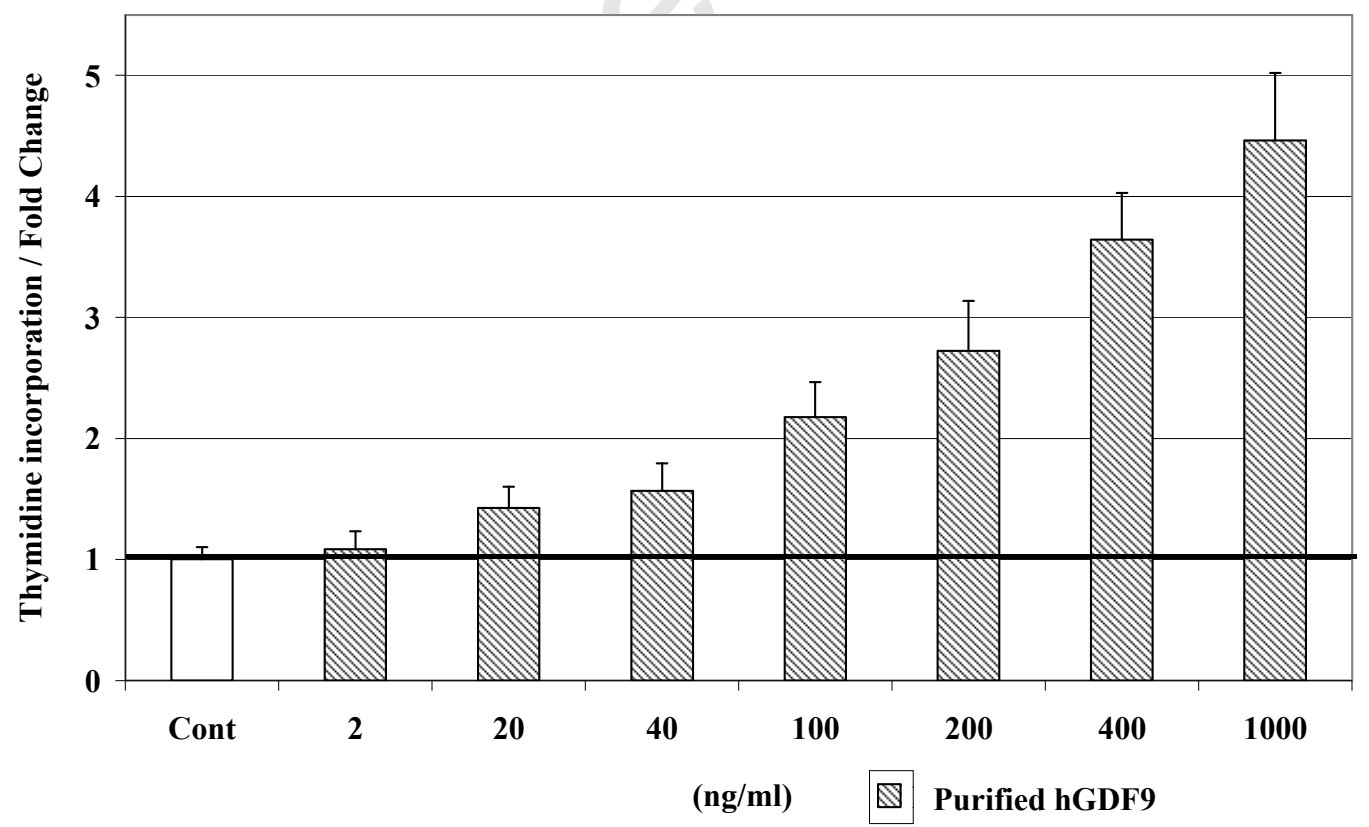




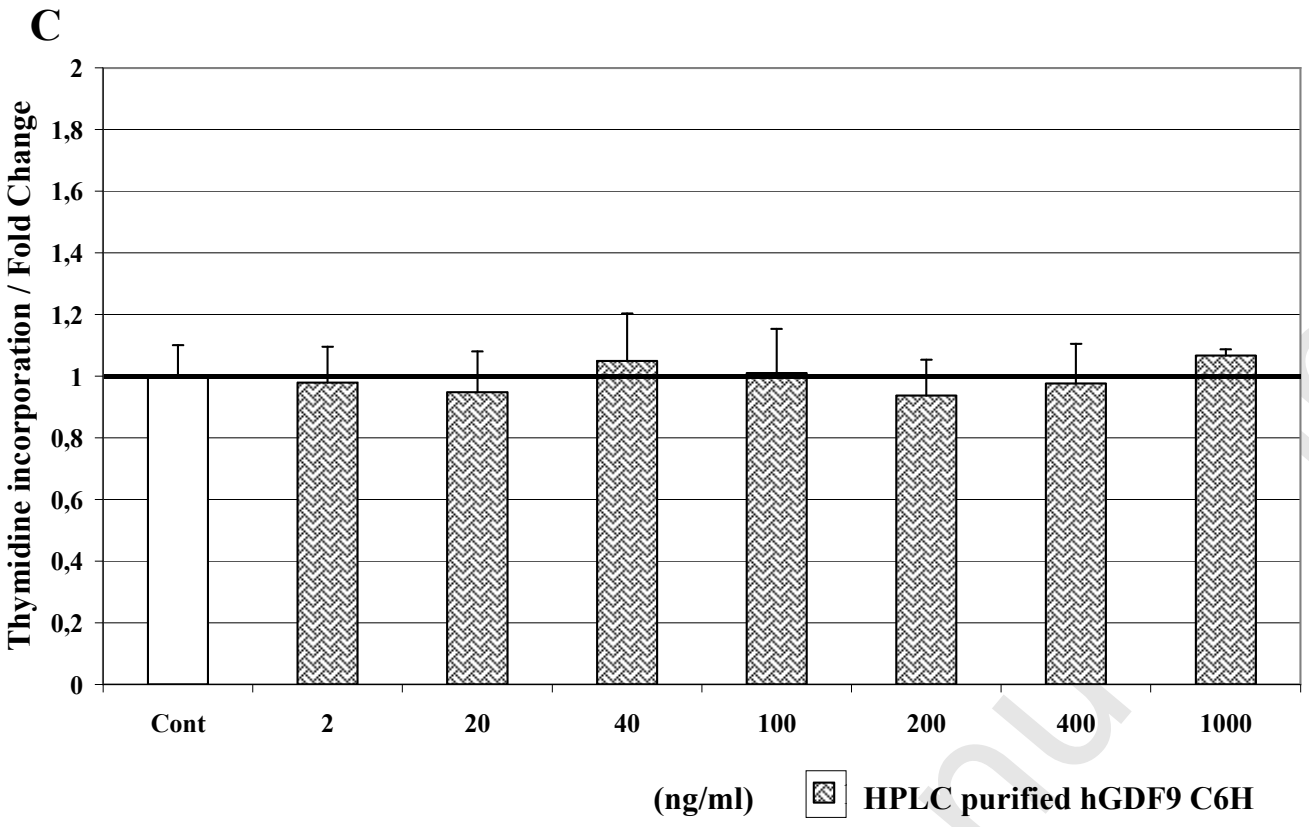

